\title{
South Africa: Detailed Assessment of Observance on the International Association of Insurance Supervisors' Insurance Core Principles
}

This paper was prepared based on the information available at the time it was completed on October 21, 2010. The views expressed in this document are those of the staff team and do not necessarily reflect the views of the government of South Africa or the Executive Board of the IMF.

The policy of publication of staff reports and other documents by the IMF allows for the deletion of market-sensitive information.

Copies of this report are available to the public from

International Monetary Fund $\bullet$ Publication Services

700 19th Street, N.W. • Washington, D.C. 20431

Telephone: (202) 623-7430 • Telefax: (202) 623-7201

E-mail: publications@imf.org • Internet: http://www.imf.org

\section{International Monetary Fund Washington, D.C.}




\section{SOUTH AFRICA}

INTERNATIONAL ASSOCIATION OF INSURANCE SUPERVISORS' INSURANCE CORE PRINCIPLES

\section{DETAILED ASSESSMENT OF OBSERVANCE}

\section{OCTOBER 2010}

INTERNATIONAL MONETARY FUND

MONETARY AND CAPITAL MARKETS DEPARTMENT
THE WORLD BANK

FINANCIAL AND PRIVATE SECTOR DEVELOPMENT VICE PRESIDENCY

AFRICA REGIONAL VICE PRESIDENCY 
I. Executive Summary, Key Findings, and Recommendations ........................................4

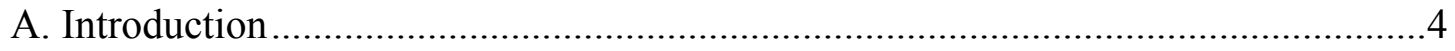

B. Information and Methodology Used for Assessment............................................4

C. Institutional and Market Structure-Overview ....................................................5

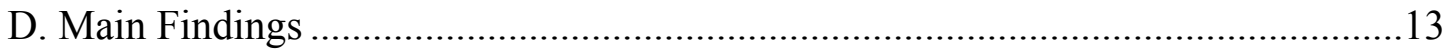

E. Recommended Action Plan and Authorities’ Response....................................19

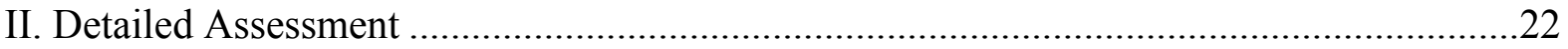

\section{Tables}

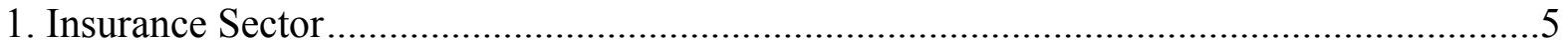



3. Key Ratios for Short-Term Insurers (Typical Insurers Only) .......................................10

4. Summary of Observance of the Insurance Core Principles ............................................15

5. Recommended Action Plan to Improve Observance of the Insurance Core Principles ......19

6. Detailed Assessment of Observance of the Insurance Core Principles ..............................22 


\section{GLOSSARY}

$\begin{array}{ll}\text { AML } & \text { Anti-money Laundering } \\ \text { ASSA } & \text { Actuarial Society of South Africa } \\ \text { BSR } & \text { Bonus Stabilization Reserve } \\ \text { CAR } & \text { Capital Adequacy Requirement } \\ \text { CDD } & \text { Customer Due Diligence } \\ \text { CMS } & \text { Council for Medical Schemes } \\ \text { ESAAMLG } & \text { Eastern and Southern Africa Anti-Money Laundering Group } \\ \text { FAIS } & \text { Financial Advisory and Intermediation Services } \\ \text { FIC } & \text { Financial Intelligence Center } \\ \text { FSB } & \text { Financial Services Board } \\ \text { GAAP } & \text { Generally Accepted Accounting Principles } \\ \text { GWP } & \text { Gross Written Premium } \\ \text { FATF } & \text { Financial Action Task Force } \\ \text { IAIS } & \text { International Association of Insurance Supervisors } \\ \text { ICP } & \text { Insurance Core Principle } \\ \text { IFAC } & \text { International Federation of Accountants } \\ \text { IFIAR } & \text { International Forum of Independent Audit Regulators } \\ \text { IFRS } & \text { International Financial Reporting Standards } \\ \text { LTIA } & \text { Long-term Insurance Act } \\ \text { MoU } & \text { Memorandum of Understanding } \\ \text { OCAR } & \text { Ordinary Capital Adequacy Requirement } \\ \text { ORSA } & \text { Own Risk and Solvency Assessment } \\ \text { PPR } & \text { Policyholder Protection Rules } \\ \text { PGN } & \text { Professional Guidance Note } \\ \text { PPFM } & \text { Principles and Practices of Financial Management } \\ \text { SADC } & \text { Southern Africa Development Community } \\ \text { SAICA } & \text { South African Institute of Chartered Accountants } \\ \text { SARS } & \text { South African Revenue Service } \\ \text { SARB } & \text { South African Reserve Bank } \\ \text { STIA } & \text { Short-term Insurance Act } \\ \text { TCAR } & \text { Termination Capital Adequacy Requirement } \\ & \end{array}$

\#4205084 
Executive Summary, Key Findings, and Recommendations

1. Insurance regulation in South Africa is sound and while the assessment identifies areas for development, these are being addressed. Overall, the Financial Services Board (FSB) takes a thorough approach to regulation, recognizing the scale and development of the South African market and the need for effective market conduct as well as prudential regulation. There are features of its work, particularly offsite supervision, which are excellent. The issues raised in the 2008 FSAP Update are all being addressed, including deficiencies in the supervision of groups. There are particular challenges in improving standards of market conduct, in both long-term (i.e., life) and short-term (i.e., nonlife) insurance. Responding to such challenges necessarily takes time, although much has already been done to strengthen enforcement efforts in particular. The FSB is appropriately taking the long view, and is committing itself to major overhauls both of financial requirements (the Solvency Assessment and Management project) and on market conduct (Treating Customers Fairly). It will require increased resources, including specialist skills, to make these projects a success.

\section{A. Introduction}

2. This assessment of South Africa's compliance with International Association of Insurance Supervisors' (IAIS) Insurance Core Principles (ICP) was carried out in March 2010. The assessment was carried out by Ian Tower, Monetary and Capital Markets Department, IMF.

\section{B. Information and Methodology Used for Assessment}

3. The assessment was based on information available in March 2010. The FSB contributed a self-assessment and further information in response to requests before and during the mission. Documentation, including relevant laws and regulations, was supplied. The findings of the 2008 FSAP Update were taken into account. The assessment has also been informed by discussions with regulators in the Insurance Division and some other units of the FSB and market participants. The assessor met with staff from the FSB; with government and insurance companies; and with industry and actuarial bodies. The assessor is grateful for the full cooperation extended by all.

\section{The assessment was based on the 2003 version of the IAIS ICPs and} Methodology. It took into account relevant IAIS standards and guidance in addition to the ICPs. The assessment of ICP 28 (anti-money laundering, combating the financing of terrorism (AML/CFT)) has been informed by a 2008 assessment of compliance with the Financial Action Task Force (FATF) AML/CFT standards by the FATF and the Eastern and Southern Africa Anti-Money Laundering Group (ESAAMLG). 


\section{Institutional and Market Structure-Overview}

5. Insurance companies are major players in the financial sector. The sector is divided between long-term insurance (broadly, life) and short-term (nonlife) insurance. Long-term companies' assets are equivalent to about 80 percent of GDP, significantly greater than both total pension fund assets and aggregate mutual funds, and equivalent to two-thirds of total banking sector assets. Insurance penetration - premiums in relation to GDP - is thirdhighest globally at 15.3 percent of GDP (2008). Overall, insurance contributes between 2 percent and 2.5 percent of South African GDP. Table 1 sets out the industry structure and key figures.

\section{Table 1. South Africa: Insurance Sector}

\begin{tabular}{|c|c|c|c|c|}
\hline $\begin{array}{l}\text { Long-term } \\
\text { Insurers }\end{array}$ & Nature of Business & $\begin{array}{l}\text { Number } \\
\text { (End- } \\
\text { 2009) }\end{array}$ & $\begin{array}{c}\text { Net } \\
\text { Premium } \\
\text { Income } \\
2009 \text { (ZAR } \\
\text { millions) } \\
\end{array}$ & $\begin{array}{l}\text { Median CAR } \\
\text { Cover Ratio } \\
(2009) \\
\end{array}$ \\
\hline Typical & $\begin{array}{l}\text { Offer all or most of the six classes of long-term } \\
\text { insurance }\end{array}$ & 28 & 176,526 & 2.9 \\
\hline Niche & Business in a specific target market only & 10 & 885 & 4.3 \\
\hline $\begin{array}{l}\text { Linked } \\
\text { investment }\end{array}$ & $\begin{array}{l}\text { Offer policies where value is linked to the value of } \\
\text { invested assets, no guarantees }\end{array}$ & 13 & 82,012 & 2.2 \\
\hline Cell captive & Undertaking business on cell captive basis only & 7 & 1,720 & 3.2 \\
\hline Reinsurers & Conduct only professional reinsurance & 7 & 4,568 & 2.2 \\
\hline Assistance & $\begin{array}{l}\text { Offer only life policies where sum assured is no } \\
\text { greater than R } 18,750 \text { (also referred to as funeral } \\
\text { policies) }\end{array}$ & 9 & 822 & 1.3 \\
\hline $\begin{array}{l}\text { Short-term } \\
\text { Insurers }\end{array}$ & Nature of Business & $\begin{array}{l}\text { Number } \\
\text { (End- } \\
\text { 2009) }\end{array}$ & $\begin{array}{l}\text { Premium } \\
\text { Income } \\
2009 \text { (ZAR } \\
\text { millions) }\end{array}$ & $\begin{array}{l}\text { Median Surplus } \\
\text { Asset Ratio } \\
\text { (Percent, 2009) }\end{array}$ \\
\hline Typical & Offer most types of short-term insurance & 25 & 39,512 & 43 \\
\hline Cell captive & Offer insurance only on a cell captive basis & 11 & 5,368 & 64 \\
\hline Captive & Undertaking business on captive basis only & 10 & 542 & 402 \\
\hline Niche & Business in a specific target market only & 34 & 5,712 & 58 \\
\hline Reinsurers & Conduct only reinsurance for the primary market & 8 & 2,314 & 243 \\
\hline
\end{tabular}


6. A key reason for the scale and significance of the long-term insurance sector is its large share of the retirement savings market. Nearly 50 percent of long-term insurance companies' balance sheets are accounted for by the underwriting of retirement fundsretirement savings vehicles, many of which are established and managed as well as underwritten by the insurance company. In addition, long-term insurance companies offer tax-advantageous retirement savings products directly to customers, including various forms of annuity.

7. The insurance sector in South Africa is characterized by:

- $\quad$ extensive interrelationships with the banks: in addition to cross-ownership, longterm insurers are a major source of funding for banks. Banks also provide a distribution channel for insurance products. However, most distribution is via agents and brokers, either tied to the insurance company or independent and servicing the wider market — or, particularly for shorter-term insurance products, directly through telesales, advertising and the internet.

- a mainly domestic orientation: with one exception, insurance companies have international operations only or mainly within the southern Africa region and, in exceptional cases, in the United Kingdom and India. The risks underwritten by longand short-term insurers are predominantly for domestic customers and, overwhelmingly, retail (including group pensions and employee benefit programs).

- a relatively advanced product offering: reinsurance and alternative risk transfer products are readily available. However, insurance companies are not engaged in wholesale credit protection business (credit default swaps, etc.) of the kind that led to heavy losses for insurers in some other markets in the global crisis. On the retail side, there has been particular innovation in retirement products and medical coverageand insurance products for HIV-infected lives. Insurers also offer retail access to hedge funds via linked investment products.

8. The insurance sector suffers from a reputation for high costs and poor treatment of customers in the past, which has led to increased regulatory intervention. A particular issue in the past was the high penalties charged on early termination of retirement and other savings policies - where long-term insurance companies sought to recover full commission (capped by regulation, but mostly paid upfront) and other costs. There had been inadequate disclosure to policyholders that such charges could be made. The companies agreed with the authorities to provide compensation for terminations since 2001. This and other issues led National Treasury (NT) to establish in 2006 a wide-ranging program to improve practices in the contractual savings market. Regulations have been made to reduce early termination penalties in the future and limit the commission that can be paid upfront on investment 
products. There are plans to address wider concerns over the impact of both high costs, including commission, and limited competition on returns available on contractual savings. ${ }^{1}$

9. The sector is also being encouraged to increase access to insurance products for poorer consumers. The Financial Sector Charter (FSC), a 2003 agreement between government and the financial services industry, committed companies to increased penetration of insurance products amongst population groups with the lowest livings standards. There are also plans for a microinsurance regulatory regime in the form of a dedicated license, although final proposals are still being worked out.

\section{Long-term insurers are particularly exposed to market and certain insurance}

risks. For many years, they have sold products with both significant guarantees and promises of equity-based returns. Some of the resulting risks are hard to hedge. Long-term insurers are, therefore, structurally exposed to falls in interest rates (which increase the value of guarantees to policyholders), and declining equity markets. They are also exposed to unexpected increases in mortality, particularly from a pandemic or unexpected worsening in HIV/AIDS mortality. Their strong position in the retirement savings markets also exposes long-term insurers to longevity risk on annuities business ${ }^{2}$.

\section{Short-term insurers are exposed to a relatively narrow range of risks. Motor} business accounts for 40 percent of gross premium income. Although losses due to motor theft have stabilized (at a high level), accident-related losses are increasing. But risks of catastrophic loss (earthquake, windstorm, etc.,) are low compared with US and European markets. This is reflected in the ready availability of reinsurance cover. However, overall risk retention (about 75 percent) is high, reflecting the predominance of motor risks, which tend to be reinsured less than large industrial and commercial risks.

\section{Long-term insurers experienced particular strains in the financial crisis,} although all insurers were affected by investment market falls. However, there were no failures of insurers directly related to the financial crisis. The effects on long-term insurers (particularly from equity market weakness given equity exposure-see Figure 1) were, for the most part, cushioned by substantial bonus stabilization reserves built up in the strong markets preceding the crisis $^{3}$; and insurers were able to benefit from the recovery in markets

\footnotetext{
${ }^{1}$ NT Discussion Paper, “Contractual Savings in the Life Industry,” March 2006.

${ }^{2}$ Stress tests done for the 2008 FSAP Update confirmed that long-term insurers were principally exposed to certain market risks and unexpected increases in mortality or longevity.

${ }^{3}$ Bonus Stabilization Reserves (BSRs) represent amounts withheld from investment returns that would otherwise be payable to policyholders in the form of bonuses during periods when returns are relatively high. Reserves are then released during periods of low returns so as to avoid the reductions in bonuses that would otherwise then be necessary. Actual approaches vary by product and company and the use of BSRs is subject to regulatory requirements - see under ICP 20, Table 3.
} 
from Q2 2009. Worsening persistency experience due to the impact of economic recession affecting disposable incomes and employment also caused significant strain. Short-term insurers were less affected, although they suffered investment losses and new business volumes fell. Exposure to hard-to-value structured finance products was limited in both the long-term and short-term sectors. Conservative approaches to risk, tight regulation (especially on insurance company investments) and remaining exchange controls ${ }^{4}$ all contributed to the relatively sound performance of insurers in the crisis.

Figure 1. South Africa: Long-Term Insurers' Assets by Type, 2008



Source: FSB.

13. For all insurers, there are risks from growing scarcity of some essential technical skills. Shortages reflect both demand and supply pressures (e.g., from emigration affecting selected skills groups). At present, the impact is mainly on costs, but worsening shortages could also lead to operational problems in the future. Equally, recession in major economies appears to have eased the pressures in some sectors by increasing the availability of certain skills.

\section{Although share prices came under pressure in the crisis, financial soundness indicators have recovered:}

\footnotetext{
${ }^{4}$ The exchange control requirements applying to long term insurers now limit foreign assets backing retail business to 20 percent of the total (nonlinked business) and 30 percent (linked business). This is a transitional regime pending further work on a continued move to reliance solely on prudential limits.
} 
- $\quad$ Share prices fell in line with insurance sector stocks globally-more so in the case of one group (Figure 2). Otherwise, market indicators for South African insurance companies are limited: no companies traded in credit default swaps.

- $\quad$ Regulatory solvency ratios remain strong, however. Insurers are required to hold free assets equal to or greater than the capital adequacy requirement (CAR) and the FSB monitors assets in excess of the CAR as a measure of financial health. Excesses for the 26 "typical" long-term insurers (see Table 2) remained high at end-2009.

Figure 2. South Africa: Share Price Movements of Major Insurance Groups

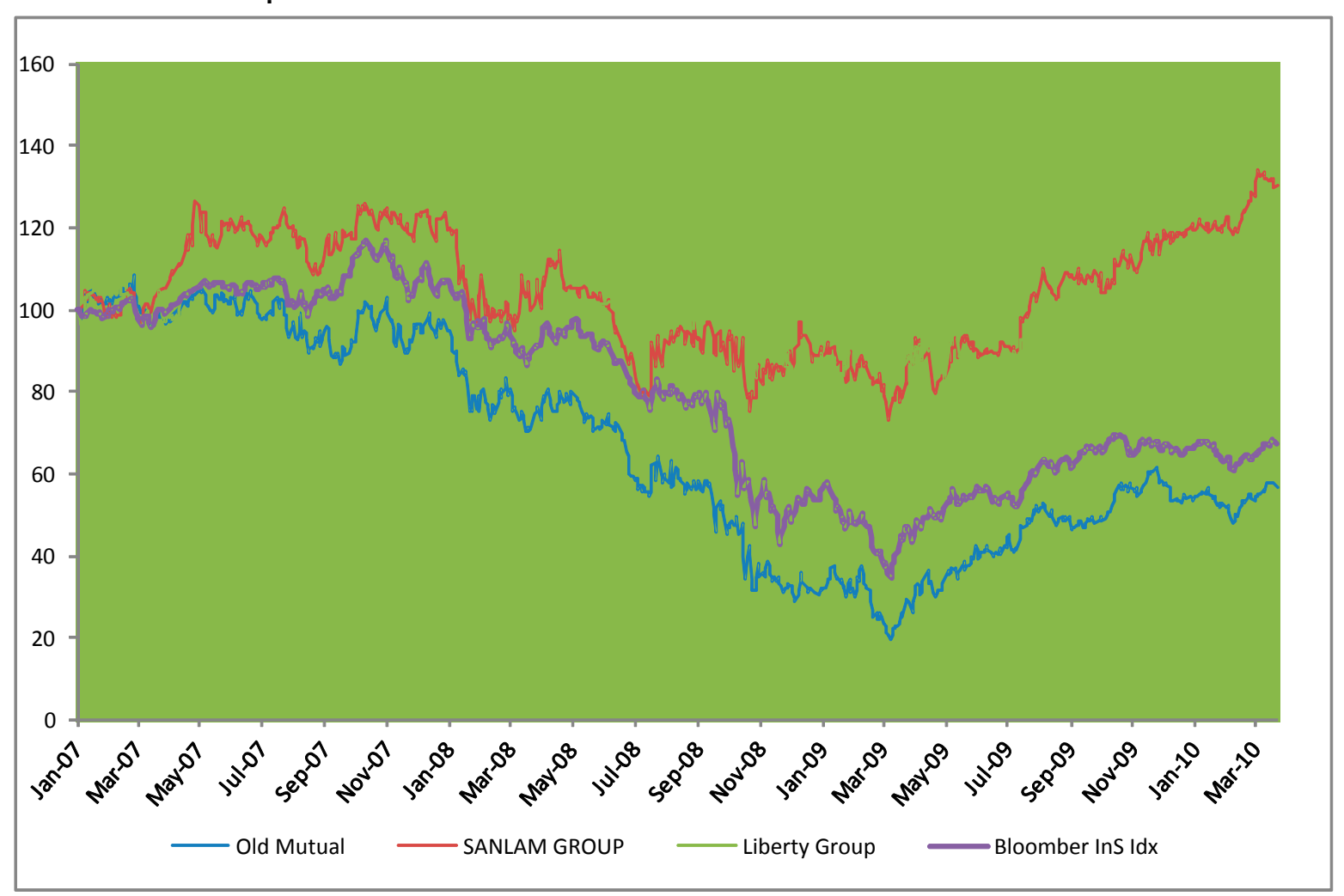

Source: Bloomberg 
Table 2. South Africa: Long-term Insurers (“Typical” Firms): Key Ratios

\begin{tabular}{|c|c|c|}
\hline & Dec. 2008 & Dec. 2009 \\
\hline \multicolumn{3}{|c|}{ Free assets to capital adequacy requirement $1 /$} \\
\hline Covered $0-1$ times & 1 & 0 \\
\hline Covered $1-2$ times & 8 & 8 \\
\hline Covered 2-5 times & 17 & 16 \\
\hline Covered $5-10$ times & 2 & 3 \\
\hline Covered $10+$ times & 1 & 1 \\
\hline Total & 29 & 28 \\
\hline Individual lapses 2/ & 59 & 63 \\
\hline Individual surrenders 2/ & 13 & 11 \\
\hline
\end{tabular}

Source: FSB Special Report on the Results of the Long-Term Insurance Industry, Dec 2009 $1 /$ Number of insurers.

2/ Percentage of number of new policies issued.

\section{Table 3. South Africa: Key Ratios for Short-Term Insurers (Typical Insurers Only)}

(Percent of net premium income)

\begin{tabular}{lcccc}
\hline & 2006 & 2007 & 2008 & 2009 \\
\hline Claims & 65 & 66 & 66 & 67 \\
Expenses & 25 & 27 & 27 & 28 \\
Combined ratio & 90 & 93 & 92 & 95 \\
Underwriting result plus & 15 & 14 & 13 & 12 \\
investment income & & & & 43 \\
Surplus asset ratio & 42 & 43 & 40 & 43 \\
\hline
\end{tabular}

Source: FSB Special Report on the Results of the Short-Term Insurance Industry, December 2009.

15. Regulation of the sector falls mainly to the Insurance Division of the FSB. The division has supervisory responsibility for both long-term and short-term insurance. Medical schemes are regulated by a separate statutory body, the Council for Medical Schemes (CMS). While sharing characteristics of insurance, these schemes are closer to social security funds - they do not underwrite individual risks. ${ }^{5}$ The FSB's Insurance Division has four departments:

\footnotetext{
${ }^{5}$ The Council regulates 119 schemes with income of R 74 billion (2008), which compares with a total of R 282 billion in insurance premiums earned in 2008.
} 
- $\quad$ Prudential (leading on supervision of financial soundness, including onsite work);

- $\quad$ Compliance (which responds to indicators of noncompliance by regulated firms and unregulated businesses);

- $\quad$ Registration (licensing of firms and approval of individuals); and

- $\quad$ Regulatory Framework (legal and policy issues).

Specialist resources are also available from within FSB, covering actuarial work and inspection (investigation of serious infringements).

\section{The Insurance Division works with other divisions of the FSB and other agencies as relevant:}

- $\quad$ Advisory and intermediation services, provided directly by insurers, are regulated by the FAIS Division of FSB.

- The Financial Intelligence Center (FIC), which works with FSB on AML/CFT issues in respect of insurance companies.

- $\quad$ Customer complaints that are not settled by firms themselves may be referred to a number of activity-based ombudsman offices. ${ }^{6}$

17. The accounting and auditing framework is in line with international standards. South Africa was an early adopter of International Financial Reporting Standards (IFRS). While the more extensive changes for insurance business will come from the IASB Phase II project on insurance accounting, scheduled for completion in 2012, South Africa has implemented IFRS 4 on insurance contracts, which has required new levels of disclosure, particularly on risk exposure and risk management. Insurance companies are required to have annual accounts audited. Major audit firms, with actuarial as well as accounting expertise, are well represented in South Africa.

\section{NT oversees FSB's regulation and leads on the broader policy program. NT} leads on changes in regulations affecting insurance companies, as major requirements take the form of government regulations rather than requirements imposed directly by the regulator. It develops policy and steers legislation through the parliament. (However, most detailed requirements are now issued directly by FSB after due consultation). The exercise of certain FSB powers still needs the consent of the Minister of Finance. In addition, NT has

\footnotetext{
${ }^{6}$ These are separate (voluntary) complaints adjudication services for long-term and short-term insurance. In addition, the (statutory) FAIS Ombudsman and the Pension Funds Adjudicator handle complaints on financial services providers (FAIS licensees) and retirement annuity products defined as pensions business under the Pensions Act.
} 
provided leadership, coordination, and much policy thinking in relation to the future regulation and development of the contractual savings market. NT also leads on broader issues of importance to insurance - planned reforms of retirement finance and social security and microinsurance.

19. A Regulators Roundtable has been meeting since 2008 to coordinate the activity of all financial regulatory and oversight authorities. The NT is coordinating regulators (i.e., the FSB, the National Credit Regulator (NCR), the South African Revenue Service (SARS), the Financial Intelligence Centre (FIC) and the South African Reserve Bank's (SARB) Banking Supervision, Financial Stability and Exchange Control Departments). The scope of the work is now developing from mainly regulatory initiatives to wider financial stability issues, including macroprudential oversight. The Roundtable would be developed into a Council of Regulators chaired by the Minister of Finance under plans announced in the 2010 budget.

20. Insurance regulation has seen some significant reforms and initiatives since the 2008 FSAP Update:

- $\quad$ FSB's enforcement approach has been significantly strengthened through legislative changes that have made it possible for administrative penalties to be levied on insurers for any breach of the regulatory requirements.

- $\quad$ CARs have been strengthened, particularly the addition of credit and operational risk requirements for long-term insurers, while higher minimum requirements have been introduced for all life insurance companies - with a particular impact on linked investment insurers, whose capital requirements were previously low.

- Initial reforms have been made under the work streams for the reform of contractual savings: regulations have been made to reduce early termination penalties and limit the commission that can be paid upfront on investment products; in other areas, such as the role of intermediaries (to distinguish commission-earning agents from feeearning brokers) the work is moving forward more slowly.

- Coordination with the banking supervisors at the SARB has been stepped up and initial steps taken on improving group and conglomerate supervision: communication between banking and insurance supervisors on operational matters in relation to the major conglomerate groups has in particular been intensified and there are moves towards greater coordination.

- Initiation of a major new project, the Solvency Assessment and Management (SAM) project to overhaul current requirements for long-term and short-term insurers: the aim of this work, which will encompass qualitative as well as quantitative requirements, is to modernize the FSB's approach in a way that will make it possible for FSB to be judged equivalent to the EU Solvency II standards. The SAM project delivers some changes in 2012, although the main impact will be in 2014. 
- A further major initiative to focus industry attention on the need to treat customers fairly: this work will also be wide-ranging, encompassing the development of market conduct standards (including consistency with other regulators such as the NCR), enforcement tools and the role of ombudsman services.

\section{Main Findings}

\section{Insurance regulation in South Africa is generally thorough and effective,} although there are areas where development is needed. Strong regulation contributed to the overall resilience of the insurance sector during the financial crisis.

- The preconditions for effective supervision are substantially met-there is in particular a sound legal and policy framework and well-developed professional services.

- $\quad$ The supervisory authority, the FSB, has extensive powers and well-established regulatory processes as well as adequate resources; there is a need to remove residual powers of intervention by government (although the FSB is apparently operationally independent) and to develop skills and expertise to help meet the challenges of major regulatory reform initiatives.

- $\quad$ The FSB cooperates extensively with other South African and with foreign regulatory authorities - and there are no legal barriers to its continuing to do so.

- $\quad$ The approach to licensing, regulation of persons and changes in control is thorough and the gaps - for example in relation to requirements on firms to notify the FSB of changes in control—are relatively minor.

- $\quad$ The FSB is aware of the importance of good internal controls, governance and risk management and assesses the adequacy of firms' approaches in its supervision work; but it needs to develop more requirements setting out its expectations in this areas.

- The FSB has an excellent framework for assessing the companies' returns and responding as appropriate; it has developed and is now implementing a risk-based model that will integrate its offsite with its already extensive onsite supervisory work and enable it to prioritize resource allocation; it should consider more extensive market wide as well as individual company risk analysis.

- $\quad$ The FSB has extensive enforcement powers which it uses where appropriate. It should have more extensive powers in relation to individuals; and there is a need for legislative change to establish a priority for policyholders in case of winding up (rare though this has been). 
- $\quad$ There is a highly developed set of requirements, supported by guidance from the actuarial profession, applying to reserving and capital adequacy, with only minor gaps, in relation to risk and control requirements for investments and derivatives. The FSB could also elaborate its approach to solvency control levels - intervention points above the statutory minimum as it may be unclear to companies at what level they are expected to maintain capital in practice.

- The regulation of intermediaries is thorough and there are extensive requirements, under insurance regulation and the law relating to advice and intermediation (FAIS) in relation to consumer protection.

- Disclosure of financial information by insurers is of a high standard, reflecting the extensive requirements applying to all public companies (which include almost all insurers); but the FSB should still consider what further information could be provided through requirements of its own.

- While the FSB addresses companies' controls against fraud in its supervision work, there are no specific requirements applying to insurers on fraud prevention. There is close cooperation between the FSB and the FIC in respect of AML/CFT requirements on insurance and extensive joint supervision work. 


\section{Table 4. South Africa: Summary of Observance of the Insurance Core Principles}

\begin{tabular}{|c|c|c|}
\hline $\begin{array}{c}\text { Insurance Core } \\
\text { Principle }\end{array}$ & Grade & Comments \\
\hline $\begin{array}{l}\text { ICP1 - } \\
\text { Conditions for } \\
\text { effective } \\
\text { insurance } \\
\text { supervision }\end{array}$ & $\mathrm{O}$ & $\begin{array}{l}\text { South Africa has a highly developed framework of laws, } \\
\text { institutions and markets that provide for the preconditions for } \\
\text { effective insurance supervision to be satisfied. Increased } \\
\text { availability of longer maturity high quality debt instruments } \\
\text { would benefit the insurance sector but can be developed only } \\
\text { over time. }\end{array}$ \\
\hline $\begin{array}{l}\text { ICP2 - } \\
\text { Supervisory } \\
\text { objectives }\end{array}$ & LO & $\begin{array}{l}\text { The FSB has a clear vision of its regulatory objectives and } \\
\text { publishes statements of its vision and mission. However, the } \\
\text { legislation itself does not contain regulatory objectives. }\end{array}$ \\
\hline $\begin{array}{l}\text { ICP3 - } \\
\text { Supervisory } \\
\text { authority }\end{array}$ & LO & $\begin{array}{l}\text { The FSB's supervision of insurance companies is carried out } \\
\text { within a clear framework of powers with a high degree of } \\
\text { independence from government. However, FSB board and } \\
\text { executive members may be removed from office by the } \\
\text { Minister of Finance without a requirement for publication of } \\
\text { reasons and the exercise of some powers is subject to } \\
\text { Minister of Finance approval. Available resources appear no } \\
\text { more than adequate given the nature of the sector and } \\
\text { planned regulatory modernization. There is a need for more } \\
\text { risk specialists. }\end{array}$ \\
\hline $\begin{array}{l}\text { ICP4 - } \\
\text { Supervisory } \\
\text { process }\end{array}$ & O & $\begin{array}{l}\text { The FSB has extensive regulatory and supervisory processes } \\
\text { and its regulatory requirements are highly transparent both to } \\
\text { regulated companies and more widely. }\end{array}$ \\
\hline $\begin{array}{l}\text { ICP5 - } \\
\text { Supervisory } \\
\text { cooperation and } \\
\text { information } \\
\text { sharing }\end{array}$ & $\mathrm{O}$ & $\begin{array}{l}\text { The FSB is empowered to exchange information with other } \\
\text { domestic and foreign regulators and does so in practice, with } \\
\text { appropriate regard to the need to ensure confidential } \\
\text { information is protected. The FSB has taken steps to ensure it } \\
\text { is ready to communicate as a home supervisor, where } \\
\text { necessary in case of crisis. }\end{array}$ \\
\hline $\begin{array}{l}\text { ICP6 - } \\
\text { Licensing }\end{array}$ & LO & $\begin{array}{l}\text { Insurance business is subject to licensing requirements and } \\
\text { there are clear minimum requirements. However, licensing } \\
\text { requirements do not sufficiently cover the need for adequate } \\
\text { governance, internal controls and risk management and more } \\
\text { friendly societies should fall within the scope of the insurance } \\
\text { legislation. }\end{array}$ \\
\hline $\begin{array}{l}\text { ICP7 - } \\
\text { Suitability of } \\
\text { persons }\end{array}$ & $\mathrm{O}$ & $\begin{array}{l}\text { The FSB has extensive powers to ensure that key } \\
\text { functionaries and shareholder controllers are fit and proper. It } \\
\text { uses its powers to ensure termination of appointment, or } \\
\text { reduction or disenfranchisement of shareholdings where it has } \\
\text { concerns. }\end{array}$ \\
\hline
\end{tabular}




\begin{tabular}{|c|c|c|}
\hline $\begin{array}{l}\text { Insurance Core } \\
\text { Principle }\end{array}$ & Grade & Comments \\
\hline $\begin{array}{l}\text { ICP8 - Changes } \\
\text { in control and } \\
\text { portfolio } \\
\text { transfers }\end{array}$ & LO & $\begin{array}{l}\text { The FSB operates with appropriate powers and processes to } \\
\text { ensure that changes of control and portfolio transfers are } \\
\text { assessed and approved only where not prejudicial to } \\
\text { policyholder interests. There are some gaps including a } \\
\text { requirement on insurance companies themselves to notify the } \\
\text { FSB when they become aware of proposed changes of control. }\end{array}$ \\
\hline $\begin{array}{l}\text { ICP9- } \\
\text { Corporate } \\
\text { governance }\end{array}$ & $\mathrm{O}$ & $\begin{array}{l}\text { While there are no explicit requirements under insurance } \\
\text { sector regulation that insurers comply with general corporate } \\
\text { governance law, insurers are subject to extensive } \\
\text { requirements, resulting from a highly developed framework of } \\
\text { Companies Act and voluntary (comply or explain) standards. }\end{array}$ \\
\hline $\begin{array}{l}\text { ICP10 - Internal } \\
\text { controls }\end{array}$ & LO & $\begin{array}{l}\text { The FSB relies extensively on the general corporate } \\
\text { governance framework, sound auditing practices and strong } \\
\text { internal control culture at insurance companies. It is } \\
\text { increasingly focusing on the assessment of control frameworks } \\
\text { in its risk-based supervisory framework. However, given the } \\
\text { insurance-specific control failures that have been experienced, } \\
\text { the FSB should consider how it can strengthen internal control } \\
\text { frameworks further in respect to insurance-specific issues. }\end{array}$ \\
\hline $\begin{array}{l}\text { ICP11 - Market } \\
\text { analysis }\end{array}$ & $\mathrm{O}$ & $\begin{array}{l}\text { The FSB has an excellent approach to the analysis of reported } \\
\text { supervisory data and publishes aggregate data and the results } \\
\text { of its analysis on the insurance sector. It should consider how } \\
\text { to make a broader analysis of wider information (including } \\
\text { market indicators and information on relevant foreign market } \\
\text { developments) and more frequent exercises to assess the } \\
\text { impact of actual or possible market wide events. }\end{array}$ \\
\hline $\begin{array}{l}\text { ICP12- } \\
\text { Reporting to } \\
\text { supervisors and } \\
\text { off-site } \\
\text { monitoring }\end{array}$ & $\mathrm{O}$ & $\begin{array}{l}\text { The FSB mandates extensive regular reporting in prescribed } \\
\text { form, both annually and reduced form unaudited quarterly } \\
\text { reports. These are subject to a comprehensive review and } \\
\text { analysis process, drawing on actuarial input and leading to } \\
\text { action, where concerns arise. Overall, the offsite supervision is } \\
\text { a considerable strength of the FSB's approach to supervision, } \\
\text { especially in the supervision of solo entities-there is more to } \\
\text { do on groups. }\end{array}$ \\
\hline $\begin{array}{l}\text { ICP13 - On-site } \\
\text { inspection }\end{array}$ & $\mathrm{O}$ & $\begin{array}{l}\text { The FSB has a well-developed approach to onsite supervision } \\
\text { that focuses on key risks and holds management to account for } \\
\text { risk management and addressing areas of regulatory concern. } \\
\text { The new risk-based approach for assessing prudential risks is } \\
\text { still being rolled out but is likely to help the FSB to further focus } \\
\text { its supervisory resources on key risk areas. }\end{array}$ \\
\hline $\begin{array}{l}\text { ICP14 - } \\
\text { Preventive and } \\
\text { corrective } \\
\text { measures }\end{array}$ & $\mathrm{O}$ & $\begin{array}{l}\text { The FSB has appropriate tools and mechanisms for identifying } \\
\text { issues at individual companies and for responding in a } \\
\text { proportionate manner with escalating severity. With the } \\
\text { exception of powers to levy fines through the Enforcement }\end{array}$ \\
\hline
\end{tabular}




\begin{tabular}{|c|c|c|}
\hline $\begin{array}{c}\text { Insurance Core } \\
\text { Principle }\end{array}$ & Grade & Comments \\
\hline & & $\begin{array}{l}\text { Committee (see ICP15), which are relatively new, the FSB's } \\
\text { formal powers and readiness to use them are well-established. }\end{array}$ \\
\hline $\begin{array}{l}\text { ICP15 - } \\
\text { Enforcement or } \\
\text { sanctions }\end{array}$ & LO & $\begin{array}{l}\text { The FSB has an extensive range of enforcement powers, } \\
\text { which have been supplemented through new powers (since } \\
2009 \text { ) to impose fines on companies and require redress, } \\
\text { subject to decision by the FSB Enforcement Committee. Use of } \\
\text { powers is relatively infrequent but they have been used. There } \\
\text { are no powers to bar individuals from acting in responsible } \\
\text { capacities in the future and the FSB's scope to impose fines } \\
\text { against individuals is limited. }\end{array}$ \\
\hline $\begin{array}{l}\text { ICP16 -Winding- } \\
\text { up or exit from } \\
\text { the market }\end{array}$ & $\mathrm{PO}$ & $\begin{array}{l}\text { The insurance legislation provides for clear triggers for the FSB } \\
\text { to take action in case of an insurance company becoming } \\
\text { financially unsound. In the event of winding-up, however, there } \\
\text { is no clear preference for insurance policyholders; nor is there } \\
\text { an insurance scheme that would pay out in case of } \\
\text { policyholder loss on an insurance company insolvency. }\end{array}$ \\
\hline $\begin{array}{l}\text { ICP17 -Group- } \\
\text { wide supervision }\end{array}$ & $\mathrm{PO}$ & $\begin{array}{l}\text { The FSB has been developing its approach to supervision of } \\
\text { groups, with more regular and extensive reporting. Cooperation } \\
\text { with the SARB on major conglomerate groups has increased. } \\
\text { There are, however, significant gaps in FSB's powers and the } \\
\text { scope of its work, which focuses mainly on financial soundness } \\
\text { and not broader issues of how groups are managed. The risk } \\
\text { assessment model does not address issues in groups. }\end{array}$ \\
\hline $\begin{array}{l}\text { ICP18 -Risk } \\
\text { assessment and } \\
\text { management }\end{array}$ & LO & $\begin{array}{l}\text { The FSB relies on reporting by insurers and its offsite and } \\
\text { onsite supervisory processes to detect and deal with risk } \\
\text { assessment and risk management weaknesses. There is a } \\
\text { need, however, for FSB to provide more feedback and } \\
\text { guidance to companies on its observations and experience of } \\
\text { good and bad risk management practices. }\end{array}$ \\
\hline $\begin{array}{l}\text { ICP19- } \\
\text { Insurance } \\
\text { activity }\end{array}$ & $\mathrm{O}$ & $\begin{array}{l}\text { The FSB takes an appropriate risk-based approach to the } \\
\text { supervision of insurance risk, relying on the statutory actuary } \\
\text { and targeted consideration of issues in individual companies. }\end{array}$ \\
\hline ICP20 -Liabilities & $\mathrm{O}$ & $\begin{array}{l}\text { Requirements on the establishment of technical provisions are } \\
\text { clearly set out and require insurers to value liabilities } \\
\text { appropriately and in some aspects conservatively. There are } \\
\text { clear provisions for the treatment of reinsurance. The FSB has } \\
\text { the authority and expertise, including in its Actuarial } \\
\text { Department, and extensive information reported by companies, } \\
\text { to assess the adequacy of technical provisions. }\end{array}$ \\
\hline $\begin{array}{l}\text { ICP21 - } \\
\text { Investments }\end{array}$ & LO & $\begin{array}{l}\text { The FSB has extensive requirements in relation to assets } \\
\text { available to meet solvency requirements - it has adopted a } \\
\text { prescriptive approach (with extensive reporting) rather than a } \\
\text { principles-based approach. However, there are gaps in } \\
\text { requirements in relation to risk management and controls over }\end{array}$ \\
\hline
\end{tabular}




\begin{tabular}{|c|c|c|}
\hline $\begin{array}{c}\text { Insurance Core } \\
\text { Principle }\end{array}$ & Grade & Comments \\
\hline & & investments. \\
\hline $\begin{array}{l}\text { ICP22 - } \\
\text { Derivatives and } \\
\text { similar } \\
\text { commitments }\end{array}$ & LO & $\begin{array}{l}\text { The FSB relies on general requirements in relation to financial } \\
\text { soundness, extensive reporting and supervision work to } \\
\text { identify and address issues with use of derivatives. The } \\
\text { approach is underpinned by requirements in the legislation that } \\
\text { limit the derivatives activities of insurers. There is a need for } \\
\text { the FSB to develop fuller requirements on the use of } \\
\text { derivatives, drawing on their experience from supervision of } \\
\text { good and bad practice. }\end{array}$ \\
\hline $\begin{array}{l}\text { ICP23 -Capital } \\
\text { adequacy and } \\
\text { solvency }\end{array}$ & $\mathrm{O}$ & $\begin{array}{l}\text { The FSB has generally well-developed standards on solvency } \\
\text { and capital adequacy. The approach is more risk-based for } \\
\text { long-term than short-term insurance. The recent extension of } \\
\text { the long-term requirements to incorporate credit and } \\
\text { operational risks has strengthened the approach significantly. } \\
\text { Insurance risks, including annuitant longevity risk, are well- } \\
\text { covered. FSB's regime will now be subject to comprehensive } \\
\text { modernization and development by } 2014 \text {, both for its own sake } \\
\text { and to ensure that it can be viewed as equivalent to the EU } \\
\text { Solvency II. FSB could consider reforms to its approach to } \\
\text { solvency control levels. }\end{array}$ \\
\hline $\begin{array}{l}\text { ICP24 - } \\
\text { Intermediaries }\end{array}$ & $\mathrm{O}$ & $\begin{array}{l}\text { The FSB's approach to intermediary regulation is relatively } \\
\text { complex, with different, if similar, legislation and rules applying } \\
\text { to insurance companies acting as distributors of their own } \\
\text { products compared with independent intermediaries; and } \\
\text { different approaches to supervision. The approach is still } \\
\text { developing. However, it appears comprehensive and FSB has } \\
\text { adequate powers to enforce compliance. }\end{array}$ \\
\hline $\begin{array}{l}\text { ICP25 - } \\
\text { Consumer } \\
\text { protection }\end{array}$ & $\mathrm{O}$ & $\begin{array}{l}\text { The FSB has a range of rules and requirements addressing } \\
\text { key areas of consumer protection for policyholders at the point } \\
\text { of sale and after sales. A range of ombudsman services } \\
\text { provide additional protection in the case of complaints } \\
\text { handling. The FSB is focusing on consumer protection in its } \\
\text { supervisory work, including through thematic programs. The } \\
\text { FSB still observes significant issues in relation to the fair } \\
\text { treatment of customers. The new powers to levy fines and } \\
\text { force compensation will help and FSB is starting a major } \\
\text { initiative to improve standards (its Treating Customers Fairly } \\
\text { program-TCF). }\end{array}$ \\
\hline $\begin{array}{l}\text { ICP26 - } \\
\text { Information, } \\
\text { disclosure and } \\
\text { transparency } \\
\text { toward markets }\end{array}$ & LO & $\begin{array}{l}\text { While the FSB has limited disclosure requirements, there is a } \\
\text { particularly wide range of information available on the financial } \\
\text { position, management and risks of insurers which are public } \\
\text { companies-almost all. }\end{array}$ \\
\hline ICP27 - Fraud & $\mathrm{PO}$ & The FSB has a high degree of awareness of fraud issues and \\
\hline
\end{tabular}




\begin{tabular}{|l|l|l|}
\hline $\begin{array}{l}\text { Insurance Core } \\
\text { Principle }\end{array}$ & Grade & \multicolumn{1}{c|}{ Comments } \\
\hline $\begin{array}{l}\text { addresses insurance companies' controls against fraud in its } \\
\text { supervision work. However, only insurance intermediaries and } \\
\text { not insurance companies are subject to specific requirements } \\
\text { on fraud prevention. }\end{array}$ \\
$\begin{array}{l}\text { ICP28 -Anti- } \\
\text { laundering, } \\
\text { combating the } \\
\text { financing of } \\
\text { terrorism }\end{array}$ & $\begin{array}{l}\text { Requirements in relation to AML/CFT issues for insurers are } \\
\text { set out in the legislation on the FIC and the role of FSB is to } \\
\text { monitor compliance with those requirements and conduct } \\
\text { compliance work. The recent FATF mutual evaluation review } \\
\text { highlighted a number of institutional weaknesses in the South } \\
\text { African approach. It remains for FSB to work with FIC to } \\
\text { ensure that overall relatively weak compliance by insurers } \\
\text { improves. }\end{array}$ \\
\hline $\begin{array}{l}\text { Aggregate: Observed (O) - 15, largely observed (LO) - 10, partly observed (PO) - 3, not } \\
\text { observed (NO) -zero, not applicable (N/A) - zero. }\end{array}$ \\
\hline
\end{tabular}

\section{E. Recommended Action Plan and Authorities' Response}

\section{Recommended action plan}

\section{Table 5. South Africa: Recommended Action Plan to Improve Observance of the Insurance Core Principles}

\begin{tabular}{|l|l|}
\hline \multicolumn{1}{|c|}{ Principle } & \multicolumn{1}{c|}{ Recommended Action } \\
\hline $\begin{array}{l}\text { ICP2 - Supervisory } \\
\text { objectives }\end{array}$ & $\begin{array}{l}\text { The FSB Act or the legislation on insurance regulation should be } \\
\text { amended to set out objectives of regulation in line with the Insurance } \\
\text { Core Principles. }\end{array}$ \\
\hline $\begin{array}{l}\text { ICP3 - Supervisory } \\
\text { authority }\end{array}$ & $\begin{array}{l}\text { Strengthening of the framework is recommended: (i) to enable the } \\
\text { FSB to set all major requirements on insurers via board notices } \\
\text { without reference to government; (ii) to set out causes for which board } \\
\text { and executive members may be removed from office and to require } \\
\text { publication of the reasons in each case; and (iii) to remove provisions } \\
\text { in the insurance legislation for the FSB's exercise of certain powers to } \\
\text { be subject to Minister of Finance approval. }\end{array}$ \\
\hline ICP6 - Licensing & $\begin{array}{l}\text { It is recommended: (i) that license requirements in the legislation are } \\
\text { extended to refer also to the need for adequate governance, internal } \\
\text { controls and risk management; (ii) that legislation is amended to bring } \\
\text { larger friendly societies within the scope of the insurance legislation; } \\
\text { and (iii) that the introduction of a microinsurance regime is expedited } \\
\text { in order to help bring basic protections to all buyers of insurance. }\end{array}$ \\
\hline
\end{tabular}




\begin{tabular}{|c|c|}
\hline Principle & Recommended Action \\
\hline $\begin{array}{l}\text { ICP8 - Changes in } \\
\text { control and portfolio } \\
\text { transfers }\end{array}$ & $\begin{array}{l}\text { It is recommended that revisions be made to the legislation to } \\
\text { complete the framework of powers-in particular: (i) to place a } \\
\text { requirement on insurance companies themselves to notify the FSB } \\
\text { when they become aware of proposed changes of control; and (ii) to } \\
\text { establish predetermined control levels in law at which further approval } \\
\text { of controllers is always required. }\end{array}$ \\
\hline ICP10 - Internal controls & $\begin{array}{l}\text { FSB should add to existing requirements in relation to internal } \\
\text { controls with new requirements, in particular on the role of internal } \\
\text { audit and controls over outsourcing. While there are already plans for } \\
\text { work in this area as part of the SAM project, the FSB could consider } \\
\text { some acceleration of this work. }\end{array}$ \\
\hline $\begin{array}{l}\text { ICP15 - Enforcement or } \\
\text { sanctions }\end{array}$ & $\begin{array}{l}\text { It is recommended that (i) the FSB be given powers to bar individuals } \\
\text { from acting in responsible capacities in the future; and (ii) that its } \\
\text { powers to impose penalties on directors, managers and employees } \\
\text { are extended. }\end{array}$ \\
\hline $\begin{array}{l}\text { ICP16 -Winding-up or exit } \\
\text { from the market }\end{array}$ & $\begin{array}{l}\text { The FSB should seek reforms to provide that in the event of winding- } \\
\text { up, there is preference for insurance policyholders; or should seek } \\
\text { provisions for an insurance scheme that would pay out in case of } \\
\text { policyholder loss on an insurance company insolvency. }\end{array}$ \\
\hline $\begin{array}{l}\text { ICP17 -Group-wide } \\
\text { supervision }\end{array}$ & $\begin{array}{l}\text { It is recommended that: (i) FSB be given additional powers to enforce } \\
\text { requirements for unregulated companies, including holding } \\
\text { companies; (ii) FSB should extend the reporting it requires of the } \\
\text { largest insurance groups to all groups and should ensure that } \\
\text { companies undertaking investment business are included in the } \\
\text { scope of consolidated supervision; and (iii) the FSB could also further } \\
\text { develop its approach to lead regulation of conglomerates in } \\
\text { cooperation with the SARB. }\end{array}$ \\
\hline $\begin{array}{l}\text { ICP18 -Risk assessment } \\
\text { and management }\end{array}$ & $\begin{array}{l}\text { It is recommended that the FSB commits to providing more feedback } \\
\text { and guidance to companies on its observations and experience of } \\
\text { good and bad risk management practices. }\end{array}$ \\
\hline $\begin{array}{l}\text { ICP19 -Derivatives and } \\
\text { similar commitments }\end{array}$ & $\begin{array}{l}\text { FSB should develop fuller requirements on the use of derivatives, } \\
\text { drawing on their experience from supervision of good and bad } \\
\text { practice. It could consider including derivatives management issues in } \\
\text { its thematic supervisory work program. }\end{array}$ \\
\hline ICP21 - Investments & $\begin{array}{l}\text { It is recommended that: (i) the FSB develop requirements on risk } \\
\text { management and controls in relation to investment assets, drawing } \\
\text { on their experience from supervision of good and bad practice; and } \\
\text { (ii) they address the lack of requirements in relation to safekeeping of } \\
\text { assets. }\end{array}$ \\
\hline $\begin{array}{l}\text { ICP26 - Information, } \\
\text { disclosure and } \\
\text { transparency toward } \\
\text { markets }\end{array}$ & $\begin{array}{l}\text { It is recommended that the FSB review the full range of disclosures } \\
\text { that would be useful to stakeholders, drawing on IAIS work, and then } \\
\text { consider to what extent these are met by existing requirements on } \\
\text { public companies and where there are gaps in available information. } \\
\text { The FSB should consider whether they can make the nonconfidential } \\
\text { parts of returns more readily available for all companies. }\end{array}$ \\
\hline ICP27 - Fraud & $\begin{array}{l}\text { It is recommended that the adequacy of FSB's powers to make and } \\
\text { enforce fraud requirements under the insurance legislation is } \\
\text { reviewed and that requirements are introduced for insurance } \\
\text { companies. }\end{array}$ \\
\hline
\end{tabular}




\section{Authorities' Response to the Assessment}

\section{IAIS insurance core principles (ICPs)}

22. Both the Treasury and the FSB find the results of the assessment to be fair, accurate and constructive. The identified areas for further development will assist the authorities to map out a comprehensive regulatory and supervisory reform agenda over the medium-term. However, the FSB would argue for a reassessment of the grade that was assigned to certain ICPs.

\section{ICP 16 (winding up or exit from the market standard)}

23. The assessment of South Africa's compliance with ICP 16 identified certain areas for improvement, highlighting the lack of a clear preference for insurance policyholders or a policyholder protection scheme that would pay out in case of policyholder loss on the insolvency of an insurer. It should be noted that the protection of policyholders' interests on the failure of an insurer is specifically recognised in the legislation that regulates the winding-up of insurers in that it obliges the Courts, when hearing an application for the winding-up of an insurer, to consider whether it is in the interest of the policyholders of the insurer that it should be wound up. The assessment of South Africa's compliance with ICP 16 must therefore be seen within this context. However, it is agreed that a more explicit form of policyholder protection may be necessary. The South African authorities plan to undertake a full analysis of the options in this regard (an explicit preference for policyholders on winding up or a policyholder protection scheme) prior to the consideration of legislative reforms. Specifically, the option of a policyholder protection scheme needs to be considered within the broader context of deliberations on insurance/protection schemes for depositors and pension fund members in South Africa. An analysis of the potential consequences of such schemes for the South African financial services sector and customers, specifically in respect of the affordability of and access to financial services and products, has still to be undertaken.

\section{ICP 17 (group-wide supervision standard)}

24. The assessment of South Africa's compliance with ICP 17 does not sufficiently recognise that group-wide supervision is still under discussion and development in most jurisdictions and within the IAIS. Even though international standards in this area are still evolving, the South African authorities have proactively launched an initiative to address group-wide supervision in the insurance regulatory and supervisory frameworks. The Solvency Assessment and Management (SAM) project recently initiated focuses on developing a new solvency regime for the South African long-term and short-term insurance industries in line with international standards, which regime will encompass supervision at both the solo entity and insurance group level. The project also has, as an overarching principle, the meeting of the requirements of a third country equivalence assessment under Solvency II. The envisaged implementation date for the new solvency regime is 2014, while interim legislative amendments to address issues such as defining the concept of insurance 
groups and the scope of insurance group supervision will be proposed for implementation late 2011 or early 2012. The authorities are confident that such interim measures will address the Partly Observant rating on ICP 17.

\section{ICP 27 (the fraud standard)}

25. The assessment of South Africa's compliance with ICP 27 recognises that the FSB has a high degree of awareness of fraud issues and addresses insurers' controls against fraud in its supervision work, but recommends that insurers be subject to specific legislative requirements on fraud prevention. This recommendation is debatable, given that:

- $\quad$ insurance fraud is not specifically criminalised because it constitutes fraud, which is a common law criminal offence;

- $\quad$ insurers, as part of the applicable corporate governance regime, are expected to ensure high standards of integrity in their business and are require to allocate appropriate resources and implement effective risk prevention procedures and controls to safeguard their financial soundness; and

- the South African insurance industry has established the South African Insurance Crime Bureau (SAICB) to provide a database of insurance fraud and to promote the exchange of information and training so as to combat insurance fraud.

26. However, the authorities will give consideration to the inclusion of an explicit legislative requirement on insurers with respect to fraud prevention as part of the periodic review and revision of South Africa's insurance legislation.

\section{Detailed AsSessment}

\section{Table 6. South Africa: Detailed Assessment of Observance of the Insurance Core Principles}

\begin{tabular}{|l|l|}
\hline Conditions for Effective Insurance Supervision \\
\hline Principle 1. & $\begin{array}{l}\text { Conditions for effective insurance supervision } \\
\text { Insurance supervision relies upon: } \\
\text { - a policy, institutional and legal framework for financial sector } \\
\text { supervision } \\
\text { - a well developed and effective financial market infrastructure } \\
\text { - efficient financial markets. }\end{array}$ \\
\hline Description & $\begin{array}{l}\text { South Africa has no explicit financial stability policy statement. However, } \\
\text { stated government policy is to provide for effective financial sector } \\
\text { supervision, principally through the SARB and the Financial Services } \\
\text { Board. SARB also has a financial stability unit charged with the } \\
\text { identification of stability threats-its remit includes the insurance sector. } \\
\text { A Regulators Roundtable has been meeting since } 2008 \text { to coordinate }\end{array}$ \\
\hline
\end{tabular}


the activities of all financial regulatory and oversight authorities (i.e., the FSB, the NCR, the SARS, the Financial Intelligence Centre and the South African Reserve Bank's Banking Supervision, Financial Stability and Exchange Control Departments) and the NT. The scope of its work is now developing from mainly regulatory initiatives to wider financial stability issues, including macroprudential oversight. South Africa is a member of the Financial Stability Board and G20. Overall, there is a high level of awareness of and focus on financial stability issues.

There is a long-established and highly developed framework of public institutions, laws and regulations covering the insurance sector and financial system generally - both general laws (company law), case law and specific laws (such as the Long Term and Short Term Insurance Acts) covering insurance.

The courts system is also well-developed and practiced in insurance issues. The 1996 Constitution provides for various levels of courts, up to the Supreme Court of Appeal and Constitutional Court. There is extensive expertise in insurance law and litigation amongst attorneys and advocates, which have established professional bodies (the Law Society and General Council of the Bar). There are alternative dispute resolution procedures addressing complaints against financial services providers (various statutory and appropriately regulated voluntary ombudsman schemes).

There is also adequate provision of other professional services, which are provided within a structure of oversight by professional and statutory bodies:

The South African Institute of Chartered Accountants (SAICA) is the principal professional body for accountants (with 28,000 members) and is an IFAC member.

Audit work for public companies is regulated by a statutory body, the Independent Regulatory Body for Auditors (IRBA), established in 2005 under the Auditing Profession Act in response to the international initiative at that time to improve audit work (IRBA is a member of the IFIAR). The IRBA registers auditors, sets auditing and ethical standards, undertakes quality assurance reviews and takes disciplinary action where necessary.

The Actuarial Society of South Africa (ASSA) is the professional body for actuaries. It issues technical guidance and sets professional conduct standards, including in relation to the role and duties of the statutory actuary (see ICP 7). ASSA is not a statutory body and is not subject to statutory oversight (it has recently established an Actuarial Governance Board to strengthen its self-regulatory functions, including oversight of the Society's disciplinary procedures).

Accounting standards are set by the Accounting Practices Board (APB) of which SAICA, the IRBA and the Johannesburg Stock Exchange 


\begin{tabular}{|c|c|}
\hline & 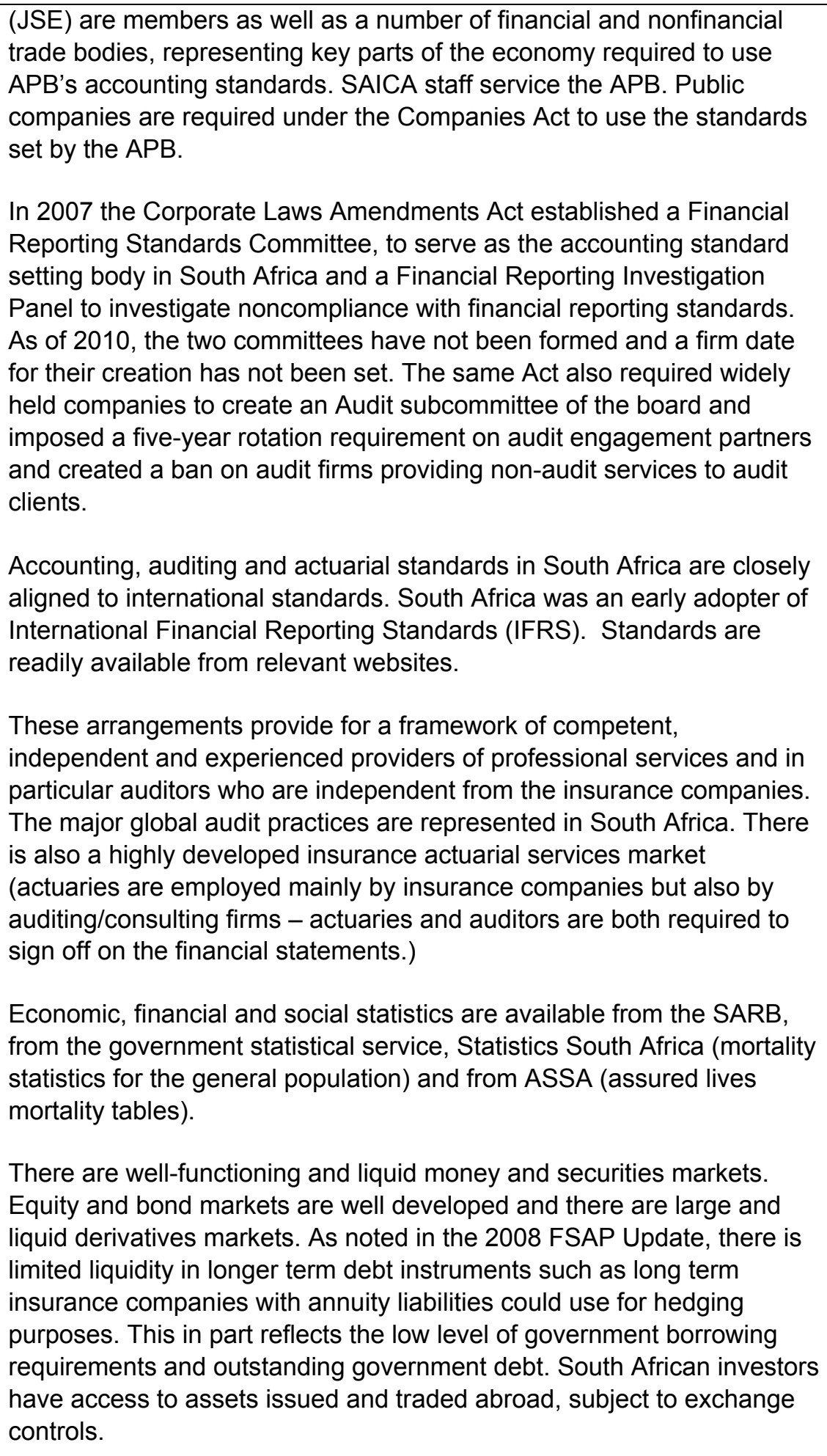 \\
\hline Assessment & Observed. \\
\hline Comments & $\begin{array}{l}\text { South Africa has a highly developed framework of laws, institutions and } \\
\text { markets that provide for the preconditions for effective insurance } \\
\text { supervision to be satisfied. Increased availability of longer maturity high }\end{array}$ \\
\hline
\end{tabular}




\begin{tabular}{|c|c|}
\hline & $\begin{array}{l}\text { quality debt instruments would benefit the insurance sector but can be } \\
\text { developed only over time. Private and public sector initiatives will } \\
\text { continue to be necessary to maintain the availability of professional } \\
\text { services, including accounting and actuarial, needed for the large and } \\
\text { highly developed South African insurance sector. }\end{array}$ \\
\hline \multicolumn{2}{|c|}{ The Supervisory System } \\
\hline Principle 2. & $\begin{array}{l}\text { Supervisory objectives } \\
\text { The principal objectives of insurance supervision are clearly defined. }\end{array}$ \\
\hline Description & $\begin{array}{l}\text { The functions of the Financial Services Board (FSB) are set out in the } \\
\text { Financial Services Board Act: } \\
\text { to supervise and enforce compliance with the laws regulating financial } \\
\text { institutions and the provision of financial services; } \\
\text { to advise the Minister of Finance on relevant matters; and } \\
\text { to promote efforts to inform and educate users of financial services } \\
\text { (Section 3). } \\
\text { The key insurance regulatory legislation, the Long-term and Short-term } \\
\text { Insurance Acts (LTIA and STIA), sets out the powers of the FSB and } \\
\text { sets certain requirements, but does not establish regulatory objectives } \\
\text { for insurance. These are set out in statements of the FSB's vision and } \\
\text { mission developed and published by the FSB itself in line with the } \\
\text { legislation. The mission refers to the promotion of: (i) fair treatment of } \\
\text { consumers, (ii) financial soundness of institutions, (iii) systemic stability } \\
\text { of financial services and (iv) the integrity of markets and institutions. } \\
\text { The FSB's strategic and business plans, also published documents, set } \\
\text { out how it proposes to deliver its objectives; and its annual report, also } \\
\text { published, sets out how it views its performance. In fact, the Public } \\
\text { Finance Management Act requires the FSB to report on: (i) its strategic } \\
\text { objectives and outcomes; (ii) key performance measures and indicators } \\
\text { for assessing its performance in delivering the desired outcomes and } \\
\text { objectives; and (iii) its actual performance against the strategic } \\
\text { objectives and outcomes. }\end{array}$ \\
\hline Assessment & Largely Observed. \\
\hline Comments & $\begin{array}{l}\text { The FSB has a clear vision of its regulatory objectives and publishes } \\
\text { statements of its vision and mission. These set out clearly appropriate } \\
\text { objectives and do not contain conflicts. However, the legislation itself } \\
\text { does not contain regulatory objectives. The FSB Act or the legislation on } \\
\text { insurance regulation should be amended to set out objectives of } \\
\text { regulation in line with the Insurance Core Principles. }\end{array}$ \\
\hline
\end{tabular}




\begin{tabular}{|c|c|}
\hline Principle 3. & $\begin{array}{l}\text { Supervisory authority } \\
\text { The supervisory authority: } \\
\text { - has adequate powers, legal protection and financial resources to } \\
\text { exercise its functions and powers } \\
\text { - is operationally independent and accountable in the exercise of its } \\
\text { functions and powers } \\
\text { - hires, trains and maintains sufficient staff with high professional } \\
\text { standards } \\
\text { - treats confidential information appropriately. }\end{array}$ \\
\hline Description &  \\
\hline
\end{tabular}


Actuary. Certain other key staff members are appointed by the Board, while the majority are appointed by the Executive Officer. The Board has various committees, including an Audit and Risk Management Committee, and an internal audit function. The EO has full authority to manage the FSB and to make all day-to-day regulatory decisions.

The Minister of Finance appoints all board members and is empowered (in the FSB Act, Section 6) to dismiss any member if the minister considers there are sufficient reasons to do so. Any such dismissal would be subject to protections under the Promotion of Administrative Justice Act of 2000, which extends rights to those affected by administrative actions, including rights to be given reasons. However, there are no stated grounds for dismissal in the FSB Act and no requirement for the reasons for a dismissal of an FSB board member to be published. There are no explicit provisions regarding dismissal of members of the executive who can in practice be dismissed at the discretion of the minister.

FSB is operationally independent from government-it makes regulatory decisions and executes them generally without reference to government. The only circumstances in which the FSB is required to obtain the approval of the Minister of Finance before taking a particular action are in respect of:

the prohibition of a long-term insurance company from carrying on business (Section 12 of the LTIA); and

initiation of winding up proceeding for a long-term or short-term insurance company (Section 42 of the LTIA and Section 41 of the STIA).

These requirements would be removed under proposed changes included in a Bill to be presented to Parliament in 2010. In practice, recent FSB experience is that where ministerial approval has been sought for such actions by the FSB, as it has been on a number of occasions, it has been obtained in line with the FSB's recommendations.

The FSB is funded entirely through levies imposed under the FSB Act on financial institutions and fees charged for services. Although the industry is consulted on proposed levies, final decisions are made by the Board. The FSB has discretion to allocate its resources in accordance with its mandate and objectives and the risks it identifies through its annual strategic planning and budgeting exercise. The strategic plan and high-level budget of the FSB must be approved by the Minister of Finance and tabled in parliament. The detailed budget is approved by the Board.

Funds received as a result of financial penalties must be placed in a segregated account for compensation of victims of violations and to pay for FSB's consumer education programs. 
Under the Promotion of Administrative Justice Act of 2000, the FSB is subject to requirements in respect of consultation, transparency and equal treatment. Legislation, regulations, rules and FSB board notices are subject to prior public consultation.

The FSB, under the FSB and Public Finance Management Acts must submit an annual report on its affairs and findings to the Minister of Finance and this report is also published.

Under the Insurance Acts and the Inspection of Financial Institutions Act, the FSB is able to act immediately and for its decisions to have immediate effect where necessary to protect policyholders' interests. The Promotion of Administrative Justice Act of 2000 allows for urgent actions.

FSB staff is required to meet high standards of professional conduct. There is a code of conduct, which includes conflict of interest provisions, adherence to which is a condition of service. One issue not covered is staff moves to employment at regulated entities, where there could be a policy requiring employees to notify their manager that they are negotiating employment with a regulated entity.

The FSB is empowered to attract and retain highly skilled staff, hire outside experts as necessary and provide training. Salaries of FSB staff are annually benchmarked to market rates.

Under the Public Finance Management Act, the FSB must prepare financial statements for each financial year in accordance with generally accepted accounting practice.

Insurance Supervision resources, which include parts of the Inspectorate and Actuarial support divisions as well as those of the Insurance Division, have been greatly increased in recent years and are being further strengthened to 70 staff this year. The increases reflect an identified need to strengthen the frontline supervisory teams, with a particular focus on larger groups, and to staff a number of major projects to develop insurance regulation that have recently been launched. A new regulatory framework function has also recently been established.

FSB staff is protected under the FSB Act from liability for loss caused by the exercise of regulatory powers in good faith.

Under the FSB and Insurance Acts, the FSB may engage external specialists under contract. Where work is outsourced or contractual agreements made, arrangements are entered into to ensure clearly defined roles and responsibilities and appropriate oversight as well as confidentiality requirements. 


\begin{tabular}{|c|c|}
\hline & $\begin{array}{l}\text { information obtained in the performance of any of its functions with } \\
\text { certain exceptions: (i) where disclosure is necessary in the course of } \\
\text { performing functions under any law; (ii) for the purposes of legal } \\
\text { proceedings; (iii) when required to do so by a court; or (iv) where the } \\
\text { board, the executive officer or deputy executive officer believe that } \\
\text { disclosure is in the public interest. Requests for any disclosure of } \\
\text { information not covered by these exemptions are rejected. }\end{array}$ \\
\hline Assessment & Largely Observed. \\
\hline Comments & $\begin{array}{l}\text { The FSB's supervision of insurance companies is carried out within a } \\
\text { clear framework of powers with a high degree of independence from } \\
\text { government, combined with appropriate accountability mechanisms. Its } \\
\text { work is carried out in a highly transparent manner. It has governance } \\
\text { and internal processes to protect it from undue industry influence. } \\
\text { Available resources appear no more than adequate, taking into account } \\
\text { the scale and significance of the South African insurance sector and the } \\
\text { need for continued modernization and development of the regulatory } \\
\text { regime. Continued attention will be required to both numbers and skills } \\
\text { of staff and there is a particular need to recruit more specialist expertise } \\
\text { in risk and risk management. } \\
\text { Some strengthening of the framework is recommended: (i) to enable the } \\
\text { FSB to set all major requirements on insurers via board notices without } \\
\text { reference to government; (ii) to set out causes for which board and } \\
\text { executive members may be removed from office and to require } \\
\text { publication of the reasons in each case; and (iii) to remove provisions in } \\
\text { the insurance legislation for the FSB's exercise of its powers to be } \\
\text { subject to Minister of Finance approval. } \\
\text { In addition, it is recommended that the staff code of conduct is } \\
\text { expanded to require employees to notify their manager when they are } \\
\text { negotiating employment with a regulated entity. }\end{array}$ \\
\hline Principle 4. & $\begin{array}{l}\text { Supervisory process } \\
\text { The supervisory authority conducts its functions in a transparent and } \\
\text { accountable manner. }\end{array}$ \\
\hline Description & $\begin{array}{l}\text { The FSB makes available all its regulatory requirements on its website, } \\
\text { updating the material as changes take effect. Other material such as } \\
\text { primary legislation is available on government websites. There is no } \\
\text { single set of requirements, such as a rulebook, but all are accessible } \\
\text { directly or via links on the FSB website. } \\
\text { The FSB considers the cost of proposed regulation in its assessment of } \\
\text { regulatory proposals. } \\
\text { The FSB uses a risk-based approach in its supervision of insurance } \\
\text { companies. This has been communicated to industry and will soon be } \\
\text { the subject of a wider publication that will be issued for public comment. } \\
\text { All decisions of the FSB under the insurance legislation are subject to } \\
\text { the Promotion of Administrative Justice Act of } 2000 \text { which enforces } \\
\text { consultation, transparency and equal treatment. The Act allows the }\end{array}$ \\
\hline
\end{tabular}




\begin{tabular}{|c|c|}
\hline & $\begin{array}{l}\text { FSB, if it is reasonable and justifiable in the circumstances (which the } \\
\text { FSB would view as covering immediate risks to policyholder interests), } \\
\text { to depart from any of the procedural requirements. } \\
\text { As mentioned under ICP3, urgent action can be taken by the FSB, } \\
\text { where necessary and the decision-taking procedures provide for this. } \\
\text { Any person may appeal against an FSB decision to the Appeal Board } \\
\text { established under Section } 26 \text { of the FSB Act. (Appeal Board members } \\
\text { are appointed by the Minister of Finance for a period of three years and } \\
\text { must include at least two professional lawyers). Beyond that, judicial } \\
\text { review (by the Courts) is also available. The FSB has been challenged } \\
\text { on significant adverse decisions taken with immediate effect and has } \\
\text { had its actions upheld. } \\
\text { As mentioned under ICP3, the FSB submits an annual report to the } \\
\text { Minister of Finance and the parliament. The annual report is also } \\
\text { published. In addition, annual reports on insurance issues are } \\
\text { published-the Annual Report of the Registrar of Long-term and Short- } \\
\text { term Insurance. These contain aggregate information about the financial } \\
\text { situation of the sector, observations on major developments and an } \\
\text { update on regulation. } \\
\text { The SARB also reports on summary insurance sector developments, } \\
\text { including financial strength indicators, in its half-yearly Financial Stability } \\
\text { Report. }\end{array}$ \\
\hline Assessment & Observed. \\
\hline Comments & $\begin{array}{l}\text { The FSB has extensive regulatory and supervisory processes and its } \\
\text { regulatory requirements are highly transparent both to regulated } \\
\text { companies and more widely. It balances the need for fair process, } \\
\text { including rights of appeal against its actions, with the need to ensure } \\
\text { that immediate regulatory action can be taken where required to protect } \\
\text { policyholders. The Regulators Roundtable established by the } \\
\text { government in } 2008 \text { (see ICP 1) is likely to become an increasingly } \\
\text { important part of the regulatory framework over time and it would be } \\
\text { appropriate to disclose more about its role and proceedings in the } \\
\text { future. The FSB could consider development of a clearer web } \\
\text { presentation of insurance rules and requirements. }\end{array}$ \\
\hline Principle 5. & $\begin{array}{l}\text { Supervisory cooperation and information sharing } \\
\text { The supervisory authority cooperates and shares information with other } \\
\text { relevant supervisors subject to confidentiality requirements. }\end{array}$ \\
\hline Description & $\begin{array}{l}\text { The FSB is empowered under the FSB Act to share information with } \\
\text { other regulators-Section } 22 \text { creates exceptions to a general } \\
\text { requirement for the preservation of confidentiality of supervisory } \\
\text { information, citing disclosure to foreign and domestic regulators, both as } \\
\text { required and under memorandums of understanding (MoUs) or other } \\
\text { forms of agreement. The same Section of the FSB Act enables the FSB } \\
\text { to impose conditions on the use of disclosed information, including in } \\
\text { relation to protection of confidentiality. There are no conditions on } \\
\text { information exchange such as existence of an MoU or one way }\end{array}$ \\
\hline
\end{tabular}




\begin{tabular}{|c|c|}
\hline & $\begin{array}{l}\text { exchange only. } \\
\text { FSB exchanges information in practice, both as a home supervisory } \\
\text { authority and a host. The nature of the international business of South } \\
\text { African insurance companies requires relatively few bilateral } \\
\text { relationships. In some cases, it is the SARB which handles the main } \\
\text { international cooperation work because the group of which the } \\
\text { insurance company is a member is headed by a bank. } \\
\text { The FSB exchanges information as required and through regular } \\
\text { meetings with other domestic regulars-the SARB, the National Credit } \\
\text { Register and the CMS. } \\
\text { The FSB is preparing an application to the IAIS to become an } \\
\text { Authorized Signatory to its Multilateral Memorandum of Understanding. } \\
\text { The FSB seeks to exchange information proactively with host } \\
\text { supervisors in respect of changes in its requirements and action that } \\
\text { would affect establishments in the host jurisdiction. Its approach reflects } \\
\text { the materiality of the establishment, in relation to the home company } \\
\text { and host market. }\end{array}$ \\
\hline Assessment & Observed. \\
\hline Comments & $\begin{array}{l}\text { The FSB is fully empowered to exchange information with other } \\
\text { domestic and foreign regulators and does so in practice, with } \\
\text { appropriate regard to the need to ensure confidential information is } \\
\text { protected. As mentioned under ICP3, it is able to protect the } \\
\text { confidentiality of information it receives. Lessons have been learned } \\
\text { from the experience of information exchange in the financial crisis and, } \\
\text { while most of these were in relation to information flow to the FSB as a } \\
\text { host supervisor, the FSB has taken steps to ensure it is ready to } \\
\text { communicate as a home supervisor, where necessary in case of crisis. }\end{array}$ \\
\hline \multicolumn{2}{|c|}{ The Supervised Entity } \\
\hline Principle 6. & $\begin{array}{l}\text { Licensing } \\
\text { An insurer must be licensed before it can operate within a jurisdiction. } \\
\text { The requirements for licensing are clear, objective and public. }\end{array}$ \\
\hline Description & $\begin{array}{l}\text { Licensing is referred to as registration under the insurance legislation. } \\
\text { The LTIA (Section 8) and STIA (Section 7) do not define what } \\
\text { constitutes insurance business and must be registered-South Africa is } \\
\text { a common law jurisdiction and the definition relies on case law. } \\
\text { Pooled health insurance business carried out in medical schemes has } \\
\text { to be registered by the Council of Medical Schemes. While sharing } \\
\text { characteristics of insurance, these schemes are closer to social security } \\
\text { funds. } \\
\text { The legislation accommodates mutual as well as corporate forms for } \\
\text { insurance companies. } \\
\text { Friendly societies are registered by the FSB under the Friendly }\end{array}$ \\
\hline
\end{tabular}


Societies Act and may carry on insurance provided that benefits do not exceed $R$ 7,500 per member (in which case societies must obtain a license under the insurance acts). Most friendly societies not also licensed as insurers are small, in terms of numbers of members and total assets but a number are substantial (the largest with R 150 million in assets)-licensing requirements and the regulatory framework generally for these companies is much less developed than for insurance companies.

Foreign companies may carry on insurance business in South Africa only through a subsidiary and under the LTIA and STIA, the FSB cannot authorize branches. Nor may foreign insurance companies (other than reinsurance companies) be licensed to offer services on a cross-border basis. A number of foreign branches of licensed South African companies offer products to South African residents and the FSB has clarified the application of its requirements in a directive (127.A.i of November 2009).

No insurance business may be conducted in South Africa without a license (or specific exemption-which is restricted to insurers regulated under other legislation and certain named institutions including Lloyd's of London). Notwithstanding the efforts of the authorities to address unregulated insurance business in the large informal sector (most of which is believed to be assistance business_funeral plans provided by funeral parlors), it remains extensive. The proposed new regime for microinsurance is expected to help address this issue.

Licenses are issued by the FSB, although advice is taken from a Licensing Committee, comprising seven persons appointed from outside the FSB. Adverse decisions may be appealed to the FSB Appeal Board (these procedures have been used in recent years).

There are clear licensing requirements set out in the legislation (LTIA and STIA, Section 9). These cover the fitness and propriety of managers and the adequacy of capital resources as well as a general condition that registration is not contrary to the public interest. Organization and management must be adequate but there is no specific provision on adequacy of risk management-the issues are, however, addressed by FSB staff in considering license applications. A five year business plan must be submitted by applicants.

If a foreign company wishes to be licensed in South Africa, it must establish and apply as a subsidiary and branches may not be authorized. The FSB seeks information from the home country supervisor of the parent company. There is no explicit provision in the LTIA or STIA for foreign-based insurance companies to offer insurance in South Africa on a cross-border basis-most such business is done via intermediaries who must be authorized in South Africa. Reinsurance may be offered direct.

All insurance companies (but not reinsurers) are required to undertake 


\begin{tabular}{|c|c|}
\hline & $\begin{array}{l}\text { only long-term or short-term insurance business. } \\
\text { The FSB may impose conditions on registration (Section } 10 \text { of each } \\
\text { Act), for example restricting the type of policies which the company may } \\
\text { write. It has frequently used this power. } \\
\text { Decisions on licenses are currently made within } 180 \text { days under } \\
\text { existing service level commitments but there are plans to shorten this } \\
\text { period. }\end{array}$ \\
\hline Assessment & Largely Observed. \\
\hline Comments & $\begin{array}{l}\text { Insurance business is subject to licensing requirements and there are } \\
\text { clear minimum requirements. The FSB has well-established processes } \\
\text { for handling license applications and is able and willing to refuse } \\
\text { applications and impose conditions on licenses where necessary. } \\
\text { It is recommended: (i) that license requirements in the legislation are } \\
\text { extended to refer also to the need for adequate governance, internal } \\
\text { controls and risk management; (ii) that legislation is amended to bring } \\
\text { larger friendly societies within the scope of the insurance legislation; } \\
\text { and (iii) that the introduction of a microinsurance regime is expedited in } \\
\text { order to help bring basic protections to all buyers of insurance. }\end{array}$ \\
\hline Principle 7. & $\begin{array}{l}\text { Suitability of persons } \\
\text { The significant owners, Board members, senior management, auditors } \\
\text { and actuaries of an insurer are fit and proper to fulfill their roles. This } \\
\text { requires that they possess the appropriate integrity, competency, } \\
\text { experience and qualifications. }\end{array}$ \\
\hline Description & $\begin{array}{l}\text { Key functionaries are identified in the LTIA and STIA as directors, } \\
\text { managing executives, public officer, auditors and the statutory actuary. } \\
\text { While auditors and actuaries are subject to direct approval by FSB, } \\
\text { requirements that directors and managers are fit and proper are } \\
\text { addressed to companies and there is no system of individual approval. } \\
\text { There is no guidance on what criteria FSB uses to determine fitness } \\
\text { and propriety for these functionaries. } \\
\text { Companies must appoint as their public officer one person to be } \\
\text { responsible for ensuring that the company complies with the regulatory } \\
\text { requirements (LTIA, Section 16). } \\
\text { The Acts provide for FSB approval of auditors (LTIA Section 19) and } \\
\text { statutory actuary (Section 20). Auditors must be registered by the IBRA } \\
\text { (see ICP1) and actuaries must be permanently resident in the Republic } \\
\text { and a Fellow of the Actuarial Society of South Africa. General } \\
\text { requirements include appropriate qualifications, professional } \\
\text { proficiency, appropriate practical experience and current knowledge on } \\
\text { developments within their profession. } \\
\text { The duties of the statutory actuary are set out in the LTIA (Section 20) } \\
\text { and STIA (Section 19A). In particular, they are required to give an } \\
\text { opinion to the FSB on relevant parts of the financial statements } \\
\text { (principally those relating to valuation of assets and liabilities). }\end{array}$ \\
\hline
\end{tabular}




\begin{tabular}{|c|c|}
\hline & $\begin{array}{l}\text { The LTIA and STIA provide for approval of shareholders with an } \\
\text { interest of } 25 \text { percent or more in the capital or voting rights of a } \\
\text { company (see ICP 8). In case the FSB considers that the retention of a } \\
\text { particular shareholder is prejudicial to the interests of the insurer, it may } \\
\text { apply to the Court for an order compelling the shareholder to reduce its } \\
\text { interest and limiting voting rights (i.e. it cannot require such action itself } \\
\text { without Court approval). See, for example, LTIA Section } 26 \text { (4). } \\
\text { FSB cooperates and exchanges information with other domestic and } \\
\text { with foreign supervisors in respect of key functionaries and shareholder } \\
\text { controllers. } \\
\text { The FSB may require termination of appointment of a key functionary } \\
\text { (directors, managing executives, public officer, auditors and the } \\
\text { statutory actuary) where it as concerns over continued fitness and } \\
\text { propriety (LTIA Section 22). } \\
\text { There are no requirements in relation to actuaries, directors and } \\
\text { managers holding two positions in an insurance company (auditors are } \\
\text { not permitted under the Companies Act to hold any position in a } \\
\text { company they audit). The FSB expects to identify any cases of potential } \\
\text { conflicts of interest as part of its supervision and to require remedial } \\
\text { action, failing which it may use its powers to require termination of } \\
\text { appointment of the relevant person. } \\
\text { While there is no requirement against it, no statutory actuary is at } \\
\text { present also a director of an insurance company. An FSB project, } \\
\text { being conducted jointly with the ASSA, is examining issues in relation to } \\
\text { the role of the statutory actuary in insurers. }\end{array}$ \\
\hline Assessment & Observed. \\
\hline Comments & $\begin{array}{l}\text { The FSB has extensive powers to ensure that key functionaries and } \\
\text { shareholder controllers are fit and proper. It uses its powers to ensure } \\
\text { termination of appointment, or reduction or disenfranchisement of } \\
\text { shareholdings where it has concerns. It should consider making formal } \\
\text { requirements in relation to statutory actuaries holding other positions in } \\
\text { the insurance company. It may also be preferable for the FSB to be } \\
\text { able to take action directly itself against shareholder controllers rather } \\
\text { than having to apply to a court. It is recommended that FSB develop } \\
\text { and publish guidance on what criteria it uses to determine fitness and } \\
\text { propriety of directors and managers. }\end{array}$ \\
\hline Principle 8. & $\begin{array}{l}\text { Changes in control and portfolio transfers } \\
\text { The supervisory authority approves or rejects proposals to acquire } \\
\text { significant ownership or any other interest in an insurer that results in } \\
\text { that person, directly or indirectly, alone or with an associate, exercising } \\
\text { control over the insurer. } \\
\text { The supervisory authority approves the portfolio transfer or merger of } \\
\text { insurance business. }\end{array}$ \\
\hline Description & The LTIA (Section 26) and STIA (Section 25) both define control by \\
\hline
\end{tabular}


reference to a person is deemed to exercise "control" over an insurer if that person, alone or with related parties, holds shares in the insurer representing 25 percent or more of the total; or holds shares which entitle that person to exercise more than 25 percent of the voting rights; or has the power to appoint or remove 25 percent or more of the directors or to prevent a person from being appointed as a director without another person's consent.

While there are no explicit provisions on ultimate rather than immediate beneficial owners - for example where there are holding companies or other such structures - the definition of control is wide enough to capture such controllers. In addition, the FSB may require an insurer or a person in whose name its shares are registered to provide details on shareholders and "of any person who directly or indirectly has the power to require those shareholders to exercise their rights as shareholders in the insurer in accordance with such person's directions or instructions" (LTIA, Section 27 (1)). Insurers are also required (LTIA, Section 25) not to register shares to any person other than the beneficial holder.

The same sections of the acts provide that no person shall, without the approval of the FSB, acquire or hold shares or any other interest in an insurer which results in that person exercising control over that insurer. There are no explicit provisions requiring insurers to notify the FSB of the change of control-the obligation falls on the potential controller.

The application requirements require detailed information similar to that required when a person applies for registration as an insurer. The FSB is required under LTIA to refuse approval if to do so would be contrary to the public interest or the interests of actual and potential policyholders. There is no reference in the legislation explicitly to fitness and propriety or financial resources but the FSB has regard to these issues in assessing whether granting approval would be in the interests of policyholders and the wider public. The FSB also has powers to impose any conditions when approving a transaction.

As with an application for a new licence, an application for the acquisition of a controlling share in an insurer is referred to the Licensing Committee for their recommendation.

There are no predetermined control levels in legislation other than the 25 percent threshold in the definition of control. Existing controllers who propose, for example, to increase their interest in an insurer from 25 percent to 51 percent are not required under the legislation to seek a new approval. In practice, the FSB attaches conditions to its approvals requiring controllers to seek further approval if they propose to go over 50 percent-and LTIA Section 26 (3)(a) explicitly provides for such conditions but leaves discretion to the FSB to determine what they should be.

The same requirements apply to foreign controllers as to domestic. 


\begin{tabular}{|c|c|}
\hline & $\begin{array}{l}\text { The insurance acts do not give the FSB power to approve, or require } \\
\text { changes to, the structures of the financial groups in order to ensure } \\
\text { transparency. However, the FSB will, if necessary, raise concerns with } \\
\text { the shareholder planning to take control or with the insurer, if it has } \\
\text { concerns about the complexity of the group structure. } \\
\text { Insurers are required to notify the FSB on a regular basis of their actual } \\
\text { controllers, including those who influenced them directly or indirectly. } \\
\text { (NB advanced criterion) } \\
\text { Portfolio transfer: } \\
\text { Under the insurance acts, insurers must obtain consent for portfolio } \\
\text { transfers. } \\
\text { In the case of the transfer of long-term insurance policies, it is } \\
\text { the High Court rather which must consider and approve such } \\
\text { transfers (LTIA, Section } 37 \text { ). The FSB has to submit a report on } \\
\text { the proposed transfer and advise the Court on whether or not it } \\
\text { has any objections to the application. Independent professional } \\
\text { persons may be appointed to assist the FSB with these } \\
\text { assessments. } \\
\text { In the case of short-term insurance policies, the FSB approves } \\
\text { transfers (STIA, Section } 36 \text { ). Similar provisions apply on } \\
\text { appointment of independent persons. } \\
\text { An amendment to the Long-term Insurance Act is being proposed by } \\
\text { the FSB to allow the FSB also to approve transfers of long-term } \\
\text { policies. } \\
\text { The LTIA (Section } 39 \text { ) and STIA (Section } 38 \text { ) make clear that the Court } \\
\text { or FSB will not approve a transfer if the transaction is inconsistent with } \\
\text { the interests of policyholders. A guideline paper issued in } 2003 \text { sets out } \\
\text { the processes to be followed in case of an application for approval of a } \\
\text { portfolio transfer. } \\
\text { satisfied that policyholders have or will be informed of the transfer and } \\
\text { have ort will give consent in writing. } \\
\text { a }\end{array}$ \\
\hline Assessment & Largely Observed. \\
\hline Comments & $\begin{array}{l}\text { The framework for changes of control and portfolios transfers contain } \\
\text { most of the required provisions and overall the FSB operates within its } \\
\text { powers and processes to ensure that changes of control and portfolio } \\
\text { transfers are assessed and approved only where not prejudicial to } \\
\text { policyholder interests. } \\
\text { It is recommended, however, that revisions be made to the legislation to } \\
\text { complete the framework of powers-in particular: (i) to place a } \\
\text { requirement on insurance companies themselves to notify the FSB }\end{array}$ \\
\hline
\end{tabular}




\begin{tabular}{|c|c|}
\hline & $\begin{array}{l}\text { when they become aware of proposed changes of control; and (ii) to } \\
\text { establish predetermined control levels in law (for example above } 50 \\
\text { percent of shares etc.,) at which further approval of controllers is always } \\
\text { required-this would improve consistency and transparency compared } \\
\text { with the current reliance on conditions. }\end{array}$ \\
\hline Principle 9. & $\begin{array}{l}\text { Corporate governance } \\
\text { The corporate governance framework recognizes and protects rights of } \\
\text { all interested parties. The supervisory authority requires compliance } \\
\text { with all applicable corporate governance standards. }\end{array}$ \\
\hline Description & $\begin{array}{l}\text { Corporate governance requirements are not included in the Insurance } \\
\text { Acts and the FSB relies extensively on a highly developed set of } \\
\text { general requirements under the Companies Act and the work of a } \\
\text { market wide body, the King Commission. The Commission has issued } \\
\text { three reports (King Reports on Governance for South Africa or "King I, II } \\
\text { and III") on broad topics of corporate governance and policy. King III in } \\
\text { particular provides a comprehensive framework of corporate } \\
\text { governance practices. } \\
\text { The Johannesburg Stock Exchange listing standards require } \\
\text { companies to either comply with the recommendations contained in or } \\
\text { explain in the annual report where they have not complied and why. } \\
\text { Under the Companies Act, directors have a clear fiduciary obligation to } \\
\text { act in the best interests of company shareholders as a whole. } \\
\text { The requirements in "King II and III" do not apply formally beyond public } \\
\text { companies at present, although there is a general expectation that they } \\
\text { will be met by companies generally. The Companies Act of } 2008 \\
\text { significantly increases legislated corporate governance requirements } \\
\text { and incorporates the corporate governance principles provided for } \\
\text { under King II-but these provisions are not yet in effect. } \\
\text { - } \\
\text { The FSB plans to assess the implications of the new Companies Act for } \\
\text { the need for insurance specific corporate governance requirements. At } \\
\text { present, it has no general corporate governance requirements applying } \\
\text { to insurance companies but does have some specific requirements in } \\
\text { relation to: } \\
\text { - } \\
\text { boards of directors, including unitary structure, independence of } \\
\text { non-executives and chair, insurance expertise (Directive 101.A.i } \\
\text { of 2004); } \\
\text { the decision-making on the exercise of discretion afforded to } \\
\text { insurers on issues such as smoothing, allocation of profits and } \\
\text { losses). Insurance companies must produce and make } \\
\text { available to policyholders a statement of their Principles and } \\
\text { - which draws on King II (Directive 138.A.i of } 2004 \text { ); } \\
\text { - }\end{array}$ \\
\hline
\end{tabular}




\begin{tabular}{|c|c|}
\hline & $\begin{array}{l}\text { Practices of Financial Management (PPFMs) setting out their } \\
\text { approach. (Directive 147.A.i of 2006-governance } \\
\text { requirements, including a recommendation on establishment of } \\
\text { a Discretionary Participation Committee, is in Section 5). } \\
\text { Compliance with these requirements and with those of the Companies } \\
\text { Act and King III are assessed during onsite visits and under the risk- } \\
\text { based supervision model (see ICP12) in the context of assigning a risk } \\
\text { rating to the company. In particular the effectiveness of board oversight } \\
\text { is evaluated as a key mitigant of the wide range of inherent risks } \\
\text { covered by the model. } \\
\text { The Insurance Acts do not yet require a dedicated compliance function } \\
\text { to be established in an insurer. However, all companies are required to } \\
\text { have an audit committee (LTIA, Section } 23 \text {, STIA, Section 22). } \\
\text { The Insurance Acts regulate reporting by a statutory actuary and } \\
\text { provides for the statutory actuary to attend and speak at a general } \\
\text { meeting of an insurer and a meeting of the board of director }\end{array}$ \\
\hline Assessment & Observed. \\
\hline Comments & $\begin{array}{l}\text { While there are no explicit requirements under insurance sector } \\
\text { regulation that insurers comply with general corporate governance law, } \\
\text { insurers are subject to extensive requirements, resulting from a highly } \\
\text { developed framework of Companies Act and voluntary (complain or } \\
\text { explain) standards. The FSB has set certain insurance specific } \\
\text { requirements, where it has felt necessary and appropriate, including the } \\
\text { governance of decision-making on discretionary participating policies. } \\
\text { FSB supervision work assesses corporate governance against } \\
\text { prevailing high standards. It should seek to identify areas for feedback } \\
\text { to insurance companies as its experience of good and bad governance } \\
\text { practices develops. }\end{array}$ \\
\hline Principle 10. & $\begin{array}{l}\text { Internal control } \\
\text { The supervisory authority requires insurers to have in place internal } \\
\text { controls that are adequate for the nature and scale of the business. The } \\
\text { oversight and reporting systems allow the Board and management to } \\
\text { monitor and control the operations. }\end{array}$ \\
\hline Description & $\begin{array}{l}\text { The FSB holds boards of directors responsible for maintaining an } \\
\text { effective internal control framework but assesses the adequacy of } \\
\text { controls as part of its supervision work. Directors are required to attest } \\
\text { to the adequacy of controls (for example, statement G8 in annual return } \\
\text { for long-term insurers, the "Risk Report Issued by Directors"). } \\
\text { The FSB relies in its overall approach to risk-based supervision as far } \\
\text { as possible on internal control functions. It includes discussions with } \\
\text { staff in such functions in its onsite work and requires access to their } \\
\text { reports (including reports of an internal audit function). It requires } \\
\text { extensive annual reporting from companies attesting to the adequacy of } \\
\text { controls. } \\
\text { Generally, there is evidence of a strong internal control culture across }\end{array}$ \\
\hline
\end{tabular}




\begin{tabular}{|c|c|}
\hline & $\begin{array}{l}\text { the insurance sector. However, there have been some systematic } \\
\text { issues and concerns with internal controls-in relation to binder } \\
\text { agreements, mainly in the short-term sector where intermediaries and } \\
\text { underwriting managers have been given extensive scope to write } \\
\text { business under delegated authority, to process claims and handle } \\
\text { relations with the policyholder. } \\
\text { FSB has some requirements of its own in relation to internal controls in } \\
\text { insurance companies. All insurers are required to have an external } \\
\text { auditor. They must establish an audit committee of the board and both } \\
\text { the LTIA and STIA set out the required functions of the committee, } \\
\text { including assisting the main board in its evaluation of the adequacy and } \\
\text { efficiency of the internal control systems. Insurers must appoint a } \\
\text { statutory actuary, which has various duties that support effective } \\
\text { internal financial controls. } \\
\text { There are, however, no regulatory requirements in relation to insurance } \\
\text { companies and: } \\
\text { - } \\
\text { basic internal controls such as separation of duties, dual control } \\
\text { of assets or accounting procedures; } \\
\text { - } \\
\text { the role of internal audit functions; } \\
\text { - } \\
\text { controls over outsourced activities and functions of the } \\
\text { insurance company; } \\
\text { compliance functions (although the public officer has some } \\
\text { statutory actuary to be present and speak at board meetings and } \\
\text { general meetings of insurance companies. } \\
\text { contexts); and }\end{array}$ \\
\hline Assessment & Largely Observed. \\
\hline Comments & $\begin{array}{l}\text { The FSB relies extensively on the general corporate governance } \\
\text { framework, sound auditing practices and strong internal control culture } \\
\text { at insurance companies, on the basis of which it seeks attestation from } \\
\text { boards, management, auditors and actuaries on the adequacy of } \\
\text { controls. It is increasingly focusing on the assessment of control } \\
\text { frameworks in its risk-based supervisory framework, although the } \\
\text { approach here (see ICP13) is still being rolled out. This approach has } \\
\text { worked well in the past. } \\
\text { However, given the insurance-specific control failures that have been } \\
\text { experienced, including in relation to binder agreements, the FSB should } \\
\text { consider how it can strengthen internal control frameworks further in }\end{array}$ \\
\hline
\end{tabular}




\begin{tabular}{|c|c|}
\hline & $\begin{array}{l}\text { respect to insurance-specific issues. It is recommend that it adds to } \\
\text { existing requirements in relation to internal controls with new } \\
\text { requirements, in particular on the role of internal audit and controls over } \\
\text { outsourcing. While there are already plans for work in this area as part } \\
\text { of the SAM project, the FSB could consider some acceleration of this } \\
\text { work. }\end{array}$ \\
\hline \multicolumn{2}{|c|}{ Ongoing Supervision } \\
\hline Principle 11. & $\begin{array}{l}\text { Market analysis } \\
\text { Making use of all available sources, the supervisory authority monitors } \\
\text { and analyses all factors that may have an impact on insurers and } \\
\text { insurance markets. It draws the conclusions and takes action as } \\
\text { appropriate. }\end{array}$ \\
\hline Description & $\begin{array}{l}\text { Regular analysis of market conditions is undertaken and reports } \\
\text { produced quarterly and annually. FSB's quarterly special reports on the } \\
\text { latest performance and financial strength indicators of the long-term } \\
\text { and short-term sectors are unusually timely and valuable (they are } \\
\text { published on the website). } \\
\text { The FSB's current work focuses mainly on the data in supervisory } \\
\text { reports, of which they present a thorough analysis, and the FSB } \\
\text { undertakes more limited work on other sources of information, including } \\
\text { information related to market conduct. There are plans to develop such } \\
\text { work in the future, when appropriate staff is recruited-market/risk } \\
\text { specialists are needed to contribute to such work in addition to } \\
\text { supervisors and other FSB staff. } \\
\text { A planned extension of annual data collection (from end-2010) to } \\
\text { include results of prescribed stress tests will add further to the FSB's } \\
\text { capacity to identify market wide risks. } \\
\text { Further analysis undertaken by the SARB for its half-yearly Financial } \\
\text { Stability Review, while further analysis of market trends and emerging } \\
\text { risks in relation to macroprudential regulation is likely to be developed } \\
\text { by the Regulators Roundtable (see ICP 1). } \\
\text { Aggregated data on the insurance sector are published by the FSB, } \\
\text { most fully in its annual reports on the long-term and short-term sectors. } \\
\text { These, however, are available after some delay and only on payment of } \\
\text { a fee. They relate to individual companies only and not to groups. } \\
\text { Consistent information on significant market developments are } \\
\text { collected by the FSB, and market wide exercises such as stress testing } \\
\text { are undertaken (most recently in the crisis where the FSB carried out } \\
\text { stress tests to assess vulnerability to further strains). } \\
\text { inalysis of relevant macroeconomic and international insurance market } \\
\text { international reach of most insurance companies. }\end{array}$ \\
\hline Assessment & Observed. \\
\hline
\end{tabular}




\begin{tabular}{|c|c|}
\hline Comments & $\begin{array}{l}\text { The FSB has an excellent approach to the analysis of reported } \\
\text { supervisory data and publishes aggregate data and the results of its } \\
\text { analysis on the insurance sector. } \\
\text { It is nonetheless recommended that FSB considers how to complement } \\
\text { its existing work with a broader analysis of wider information (including } \\
\text { market indicators and information on relevant foreign market } \\
\text { developments) and with more frequent exercises to assess the impact } \\
\text { of actual or possible market wide events (such as a flu pandemic, major } \\
\text { emergency etc.) This will require the recruitment of more specialist } \\
\text { expertise in risk and risk management. } \\
\text { As in all countries, there is a need to develop a macroprudential } \\
\text { surveillance, which should include issues related to the close links } \\
\text { between banks and insurers in South Africa such as the potential for } \\
\text { increased regulatory arbitrage between the two regulatory regimes. } \\
\text { Annual aggregate data could be made available more quickly than at } \\
\text { present and without charge. }\end{array}$ \\
\hline Principle 12. & $\begin{array}{l}\text { Reporting to supervisors and off-site monitoring } \\
\text { The supervisory authority receives necessary information to conduct } \\
\text { effective off-site monitoring and to evaluate the condition of each } \\
\text { insurer as well as the insurance market. }\end{array}$ \\
\hline Description & $\begin{array}{l}\text { The FSB requires (e.g., in LTIA, Section } 36 \text { ) insurers to submit annual } \\
\text { statutory returns with a prescribed form and content. These annual } \\
\text { returns must be audited-the return includes a statement to be } \\
\text { completed by the auditors giving the audit opinion. Insurers are also } \\
\text { required to submit unaudited quarterly returns. Where an insurer is } \\
\text { rated as high-risk, it is generally required also to submit monthly } \\
\text { returns. The FSB has powers to require an inadequate return to be } \\
\text { resubmitted. It can impose sanctions for late or inadequate returns. } \\
\text { The framework treats all forms of insurance company similarly - all } \\
\text { registered insurers must submit the same annual statutory return. } \\
\text { Branch business is not permitted. The framework does not distinguish } \\
\text { between privately owned or government owned insurers (of which there } \\
\text { are several). } \\
\text { The prescribed returns are submitted on a solo basis for all registered } \\
\text { insurance companies. Insurance groups that are of systemic } \\
\text { importance are required to submit quarterly unaudited returns on a } \\
\text { group wide basis. Legislation provides the FSB with the power to } \\
\text { request whatever information may be needed (e.g., Section } 4 \text { of the } \\
\text { LTIA-and failure to comply is an offence under Section } 67 \text { ). } \\
\text { The FSB is currently working on refining the reporting requirements for } \\
\text { Insurance Groups. This work is expected to be finalised by June } 2010 \text {. } \\
\text { The FSB prescribes the accounting basis to be used for reporting and } \\
\text { the scope of reporting, which includes off-balance sheet business and } \\
\text { valuation approaches for guarantees (Board Notice } 14 \text { of } 2010 \text { and }\end{array}$ \\
\hline
\end{tabular}




\begin{tabular}{|c|c|}
\hline & $\begin{array}{l}\text { PGN } 104 \text { and Board Notice } 27 \text { of } 2010 \text { for long-term and short-term } \\
\text { business respectively). Returns must be signed by the public officer - } \\
\text { the official which each company must appoint (e.g., under Section } 16 \text { of } \\
\text { the LTIA) to take responsibility for compliance with regulatory } \\
\text { requirements; and certain statements also require signature by the } \\
\text { chairman of the board and a director. } \\
\text { The FSB analyzes all reported information, makes comprehensive } \\
\text { internal reports and takes action on the basis of its analysis, where } \\
\text { required to address issues or concerns highlighted by the reports. The } \\
\text { Actuarial Department reviews all the returns and advises supervisors on } \\
\text { technical issues in the high priority cases or as requested by the } \\
\text { supervisors. Questions and concerns are taken up with companies } \\
\text { promptly and reported up the management chain for information and } \\
\text { discussion. } \\
\text { The content of returns is reviewed annually to ensure that they are up } \\
\text { to date and there have been a number of changes. The LTIA and STIA } \\
\text { require an insurer which fails to comply with any requirements relating } \\
\text { to financial soundness to notify the FSB of the failure and give reasons } \\
\text { (NB - advanced criteria). }\end{array}$ \\
\hline Assessment & Observed. \\
\hline Comments & $\begin{array}{l}\text { The FSB mandates extensive regular reporting in prescribed form, both } \\
\text { annually (a full, audited report with qualitative and quantitative } \\
\text { information) and reduced form unaudited quarterly reports. These are } \\
\text { subject to a thorough and comprehensive review and analysis process, } \\
\text { drawing on expert actuarial input and leading to action, where concerns } \\
\text { arise. Overall, the offsite supervision is a considerable strength of the } \\
\text { FSB's approach to supervision, especially in the supervision of solo } \\
\text { entities-as FSB acknowledges, there is more to do on groups. }\end{array}$ \\
\hline Principle 13. & $\begin{array}{l}\text { On-site inspection } \\
\text { The supervisory authority carries out on-site inspections to examine the } \\
\text { business of an insurer and its compliance with legislation and } \\
\text { supervisory requirements. }\end{array}$ \\
\hline Description & $\begin{array}{l}\text { The Insurance Acts and the Inspection of Financial Institutions Act } \\
\text { empower the FSB to conduct on-site supervision, using two } \\
\text { approaches: } \\
\text { - The Insurance Division or FAIS Division may visit an insurer to } \\
\text { assess developments in the business, risk management and } \\
\text { compliance (this is termed an on-site visit) as part of company } \\
\text { specific supervision or for thematic work; onsite work in relation } \\
\text { to prudential matters and market conduct have traditionally } \\
\text { been conducted separately but are increasingly integrated- } \\
\text { joint visits are undertaken. } \\
\text { Where supervisors suspect that there has been material } \\
\text { noncompliance that should be investigated, the onsite work is } \\
\text { generally performed by the Inspectorate Department using the } \\
\text { FSB's wide-ranging search and seizure powers under the }\end{array}$ \\
\hline
\end{tabular}


Inspection of Financial Institutions Act-this is termed an inspection. The Inspectorate Department has its own resources, mostly legal and accounting professionals rather than insurance experts.

The FSB does not normally use external auditors for onsite supervision work.

The FSB has long been conducting on-site work. In the Insurance Division since June 2009 it has been operating a risk-based approach based on that of the Canadian prudential supervisor. Companies which have been covered by the on-site visit programme have been given initial risk ratings based on analysis of reported data, information from the market conduct monitoring (e.g., complaints data) and public information. This initial rating is reviewed by a panel of senior staff and finalized after onsite work in the light of findings. Risk assessments are further reviewed each quarter in the light of the returns and other developments. The frequency of onsite work is now driven by the risk rating but each company will be visited at minimum once every three years.

Risk assessments of all insurers in respect of which on-site visits were undertaken in 2009 have been completed. During 2010, risk assessments will be done on an off-site basis for all other insurance companies

The design of the risk model is orientated towards prudential supervision: market conduct and related risk is captured by a risk category of legal and regulatory risk. The other risks assessed are market, credit, insurance, operational, liquidity and strategic. Scores (Low, Moderate, Above Average and High) are assigned to net risk (taking account of the assessed quality of risk management) and an overall (composite) risk score assigned. The FSB envisages applying different intervention tools according to the composite risk score but on a judgmental rather than automatic basis (see also ICP14).

There is a separate risk model for insurance companies that are also subject to supervision by the FAIS department in respect to their advisory business. A current project is addressing possible integration of the risk models.

Once the risk-based model is fully rolled out, reports of onsite work and required action will be communicated to companies within 45 days. Companies are not currently informed of their risk rating but will be in future, once the risk model is rolled out in full. The FSB follows up on required actions.

The FSB has also recently started to undertake thematic on-site work, focused on market conduct issues.

Onsite work may be extended to institutions undertaking outsourced 


\begin{tabular}{|c|c|}
\hline & $\begin{array}{l}\text { functions for insurance companies. Where necessary, such work is } \\
\text { authorised under the Inspection of Inspection of Financial Institutions } \\
\text { Act, which contains the fullest powers. }\end{array}$ \\
\hline Assessment & Observed. \\
\hline Comments & $\begin{array}{l}\text { The FSB has a well-developed approach to onsite supervision that } \\
\text { focuses on key risks and holds management to account for risk } \\
\text { management and addressing areas of regulatory concern. The new } \\
\text { risk-based approach for assessing prudential risks is still being rolled } \\
\text { out but is likely to help FSB further focus its supervisory resources on } \\
\text { key risk areas. The rollout has been accompanied by some delays in } \\
\text { communication with firms but these should be addressed by service } \\
\text { level commitments. The greater integration of the differing risk models } \\
\text { used for prudential and market conduct, as well as more joint visit work, } \\
\text { and the extension of risk models to groups will help FSB improve } \\
\text { effectiveness of onsite work still further. }\end{array}$ \\
\hline Principle 14. & $\begin{array}{l}\text { Preventive and Corrective Measures } \\
\text { The supervisory authority takes preventive and corrective measures } \\
\text { that are timely, suitable and necessary to achieve the objectives of } \\
\text { insurance supervision. }\end{array}$ \\
\hline Description & $\begin{array}{l}\text { The legislation governing FSB's work provides it with a wide range of } \\
\text { remedies to address actual or potential noncompliance by an insurer. It } \\
\text { can look to its extensive reporting requirements, especially the annual } \\
\text { returns but also specific notifications such as terminations of key } \\
\text { appointments, and its developing approach to onsite supervision, to } \\
\text { identify concerns at an early stage. Together, these create an } \\
\text { expectation that companies will report problems at an early stage. } \\
\text { There are also duties on auditors and actuaries to report concerns to } \\
\text { the FSB. For example, under the LTIA, Section 19, auditors of long- } \\
\text { term insurers must report to the FSB in case of termination of their } \\
\text { appointment and on any potential contravention of financial soundness } \\
\text { requirements. Certain communications by auditors to companies must } \\
\text { be copied to the FSB. Supervisors increasingly meet auditors as part of } \\
\text { the risk-based onsite work. } \\
\text { FSB's supervisors aim to address minor issues and concerns that are } \\
\text { at an early stage through discussion with company management. In } \\
\text { general, senior supervisors appear to have the standing with } \\
\text { companies and the depth and range of relationships with management } \\
\text { to bring about appropriate corrective action without the need for use of } \\
\text { formal powers. Those powers include the issuing of directives (to } \\
\text { undertake or desist from undertaking certain actions), and the limitation } \\
\text { or prohibition of insurance business, registration conditions or ultimately } \\
\text { the removal of a license and winding-up (see ICPs } 15 \text { and } 16 \text { ). There is } \\
\text { progressive escalation in the use of powers subject to a readiness to } \\
\text { move to urgent action, however severe, where required to protect } \\
\text { policyholders. } \\
\text { In respect to financial soundness indicators, there are no formal triggers } \\
\text { (or solvency control levels) leading to specific forms of intervention }\end{array}$ \\
\hline
\end{tabular}




\begin{tabular}{|l|l|}
\hline & $\begin{array}{l}\text { (although there are internal guidelines to assist staff in deciding on } \\
\text { appropriate actions). } \\
\text { The FSB can and does require insurers to provide, within a prescribed } \\
\text { time period, an action plan on how they will address financial } \\
\text { soundness concerns. (LTIA, Section 35, STIA Section 34). }\end{array}$ \\
\hline Assessment & Observed. \\
\hline Comments & $\begin{array}{l}\text { The FSB has appropriate tools and mechanisms for identifying issues } \\
\text { at individual companies (including requirements on companies, auditors } \\
\text { and actuaries to report problems) and for responding in a proportionate } \\
\text { manner with escalating severity. It is helpful in this regard that, with } \\
\text { the exception of powers to levy fines through the Enforcement } \\
\text { Committee (see ICP15), which are relatively new, the FSB's formal } \\
\text { powers and readiness to use them are well-established. The } \\
\text { establishment of more formal solvency control levels governing } \\
\text { intervention on financial soundness issues would be helpful. FSB will be } \\
\text { reviewing its approach in this area as part of the rollout of risk-based } \\
\text { supervision and SAM project. }\end{array}$ \\
& $\begin{array}{l}\text { Enforcement or sanctions } \\
\text { The supervisory authority enforces corrective action and, where } \\
\text { needed, imposes sanctions based on clear and objective criteria that } \\
\text { are publicly disclosed. }\end{array}$ \\
\hline Principle 15.
\end{tabular}

Description

The Registrar has an extensive range of enforcement powers-the recent addition of administrative penalties through the extension of the scope of the FSB's Enforcement Committee is a significant recent development. Penalties may be levied for any breach of the FSB's requirements.

- $\quad$ The FSB can issue directives to an insurer to undertake or desist from undertaking certain actions. Failure to comply with a directive constitutes noncompliance with the Act and may be referred to the administrative enforcement committee of the FSB. (LTIA and STIA, Section 4(a)).

- $\quad$ The Acts also provide for the limitation or (in defined circumstances such as with the approval of the Minister) prohibition of insurance business undertaken (LTIA and STIA, Sections 11 and 12).

- Where an insurer is financially unsound (i.e., is not meeting, or is likely in a reasonable period, not to meet the minimum solvency requirements), the FSB may direct (LTIA Section 35, STIA Section 34 ) that insurer to take a specific course of action, which may include a compulsory transfer of business to another willing insurer. (In addition, an insurer may not declare or pay dividends if it is financially unsound-LTIA Section 29(4)).

The FSB can request a company to, for example, maintain a level of solvency cover above the minimum but it cannot require it to do so. 
Dividend payments are prohibited only in cases of financial unsoundness.

The Acts do not provide for an action to be taken against activities of subsidiaries.

The FSB can require an insurer to terminate the appointment of a director, managing executive, public officer, auditor or statutory actuary, if the person or firm concerned is not fit and proper to hold the office concerned (see ICP 7); and can apply to Court for action in respect of shareholder controllers (ICP 8).

The FSB may, where an insurer is financially unsound, apply to the Court for curatorship (Financial Institutions (Protection of Funds) Act, Section 5) or a judicial management order (LTIA, Section 41, STIA, Section 40). This is a form of curatorship or administration under which a Court-appointed manager takes controls of the affairs of a company (the main provisions are in the Companies Act 1973), with a view to determining the best strategy for managing the business. The FSB has used this power in respect of a long-term insurer in the last year.

The Financial Services Laws General Amendment Act, 2008 and the Insurance Laws Amendment Act, 2008, significantly enhanced the enforcement capabilities of the FSB through the establishment of an administrative enforcement committee. The administrative enforcement committee may impose (unlimited) fines and order compensation to be paid to policyholders, where appropriate.

The Enforcement Committee can impose fines on companies and individuals where they are subject to specific obligations in legislation (such as statutory actuaries or directors, employees and agents in respect of obligations under the Financial Institutions (Protection of Funds) Act). The FSB has no powers to bar individuals from acting in responsible capacities in the future.

Failure to provide information or false information may give rise to the Registrar taking remedial action set out above. The provision of false information is a criminal offence in certain instances.

The Registrar may terminate an insurer's registration (LTIA and STIA, Sections 11) if:

- $\quad$ an insurer fails to commence carrying on business within a reasonable period after being registered;

- $\quad$ an insurer has ceased to enter into polices to an extent which no longer justifies its continued registration;

- $\quad$ an insurer has notified the Registrar of its intention to cease to enter into any more polices and has requested so in writing;

- the FSB considers it appropriate to act so in accordance with the 


\begin{tabular}{|c|c|}
\hline & $\begin{array}{l}\text { provision where an insurer has been prohibited from carrying on } \\
\text { certain insurance business; } \\
\text { when the business of an insurer has been discontinued as a result } \\
\text { of its amalgamation with, or its transfer to, another insurer; or it is } \\
\text { wound up. } \\
\text { An insurer must be a separate registered legal entity and as such enjoys } \\
\text { some protection against unreasonable actions by its holding company or } \\
\text { any other entity within a group. The Act places limitations on certain } \\
\text { actions, where such actions will cause the insurer to be financially } \\
\text { unsound, such as limitations on the transfer of assets and declaration of } \\
\text { dividends. } \\
\text { The FSB has internal decision-taking processes that help to ensure } \\
\text { consistence in its application of its enforcement powers, including the } \\
\text { Enforcement Committee. } \\
\text { A number of persons conducting unregistered insurance business have } \\
\text { been referred to the Enforcement Committee and the National Prosecuting } \\
\text { Authority. }\end{array}$ \\
\hline Assessment & Largely Observed. \\
\hline Comments & $\begin{array}{l}\text { The FSB has an extensive range of enforcement powers, which have been } \\
\text { supplemented through new powers (since 2009) to impose fines on } \\
\text { companies and require redress, subject to decision by the FSB } \\
\text { Enforcement Committee. Use of powers is relatively infrequent- the FSB } \\
\text { aims to address problems and secure remedial action before the use of } \\
\text { formal powers becomes necessary. However, powers have been used- } \\
\text { including the imposition of fines in one case of unlicensed insurance } \\
\text { business. The FSB's enforcement powers enable it to take action against } \\
\text { individuals but its scope to impose fines against individuals is limited and } \\
\text { would not cover mistreatment of policyholders, for example. It is } \\
\text { recommended that (i) the FSB be given powers to bar individuals from } \\
\text { acting in responsible capacities in the future; and (ii) that its powers to } \\
\text { impose penalties on directors, managers and employees are extended. }\end{array}$ \\
\hline Principle 16. & $\begin{array}{l}\text { Winding-up and exit from the market } \\
\text { The legal and regulatory framework defines a range of options for the } \\
\text { orderly exit of insurers from the marketplace. It defines insolvency and } \\
\text { establishes the criteria and procedure for dealing with insolvency. In the } \\
\text { event of winding-up proceedings, the legal framework gives priority to } \\
\text { the protection of policyholders. }\end{array}$ \\
\hline Description & $\begin{array}{l}\text { Under the insurance acts, an insurer is in a financially unsound condition } \\
\text { (so triggering a range of FSB powers) when it is unable (or likely to } \\
\text { become unable) to meet the financial requirements in Part IV of the } \\
\text { relevant act (i.e., it is unable to meet its liabilities and capital adequacy } \\
\text { requirement). At this point, the FSB may ask the company for remedial } \\
\text { plans (see ICP14), may make other requirements of the company or, "if } \\
\text { reasonably necessary in the interests of policyholders" may proceed to } \\
\text { apply to the Court either for curatorship (Financial Institutions (Protection }\end{array}$ \\
\hline
\end{tabular}




\begin{tabular}{|c|c|}
\hline & $\begin{array}{l}\text { of Funds) Act, Section 5), judicial management or for a Court-order } \\
\text { winding-up (LTIA, Section 35, STIA, Section 34). } \\
\text { The FSB may apply to Court for the winding-up of an insurer (LTIA, } \\
\text { Section 42, STIA, Section 41)-provided that the Minister of Finance } \\
\text { consents. The FSB must in the application explain why it is in the interest } \\
\text { of the policyholders that an insurer should be wound up. Any court } \\
\text { application by a person, other than the FSB, for winding-up may not be } \\
\text { heard unless all relevant documents were also served on the FSB. The } \\
\text { FSB may, if satisfied that the application is contrary to the interests of the } \\
\text { policyholders of the long-term insurer, join the application as a party and } \\
\text { file affidavits and other documents in opposition to the application. } \\
\text { The insurance acts also provide for the voluntary winding-up of an insurer } \\
\text { or winding-up by Court order (LTIA, Section 43, STIA, Section } 42 \text { ). } \\
\text { The provisions of the Companies Act and the Insolvency Act of } 1936 \text { apply } \\
\text { in respect of winding-up processes and procedures. The latter Act also } \\
\text { specifies when winding-up may take place (including the actions that is } \\
\text { regarded as an "act of insolvency") and specifies the point at which an } \\
\text { insurer may no longer conduct business. }\end{array}$ \\
\hline Assessment & Partially Observed. \\
\hline Comments & $\begin{array}{l}\text { The insurance legislation provides for clear triggers for the FSB to take } \\
\text { action in case of an insurance company becoming financially unsound, } \\
\text { including making an application for a Court-ordered winding-up. Such } \\
\text { winding-up can therefore take place in advance of the insurance company } \\
\text { becoming insolvent (on a Companies Act definition of insolvency). In the } \\
\text { event of winding-up, there is no preference for insurance policyholders; } \\
\text { nor are there provisions for policyholder protection such as an insurance } \\
\text { scheme that would pay out in case of policyholder loss on an insurance } \\
\text { company insolvency. While insurance company windings-up are expected } \\
\text { to remain rare, this issue should be addressed. }\end{array}$ \\
\hline Principle 17. & $\begin{array}{l}\text { Group-wide supervision } \\
\text { The supervisory authority supervises its insurers on a solo and a group- } \\
\text { wide basis. }\end{array}$ \\
\hline Description & $\begin{array}{l}\text { There are no requirements in law or under the FSB's powers, nor any } \\
\text { published guidance or other information at present in relation to group } \\
\text { wide supervision. } \\
\text { The FSB's current approach is therefore relatively informal and relies, in } \\
\text { respect to information gathering on groups and follow-up action, on the } \\
\text { general authority and standing of the regulator rather than specific } \\
\text { provisions. In particular, group reporting (standard returns) is relatively } \\
\text { undeveloped; the scope of group supervision is only up to the insurance } \\
\text { group holding company level within South Africa and covers only financial } \\
\text { conglomerates (i.e., where the group includes one or more insurance } \\
\text { companies and another financial institution); and the FSB's risk-based } \\
\text { supervisory model does not apply to groups (i.e., assessment and risk } \\
\text { ratings are given only to the individual insurance companies in a group). }\end{array}$ \\
\hline
\end{tabular}




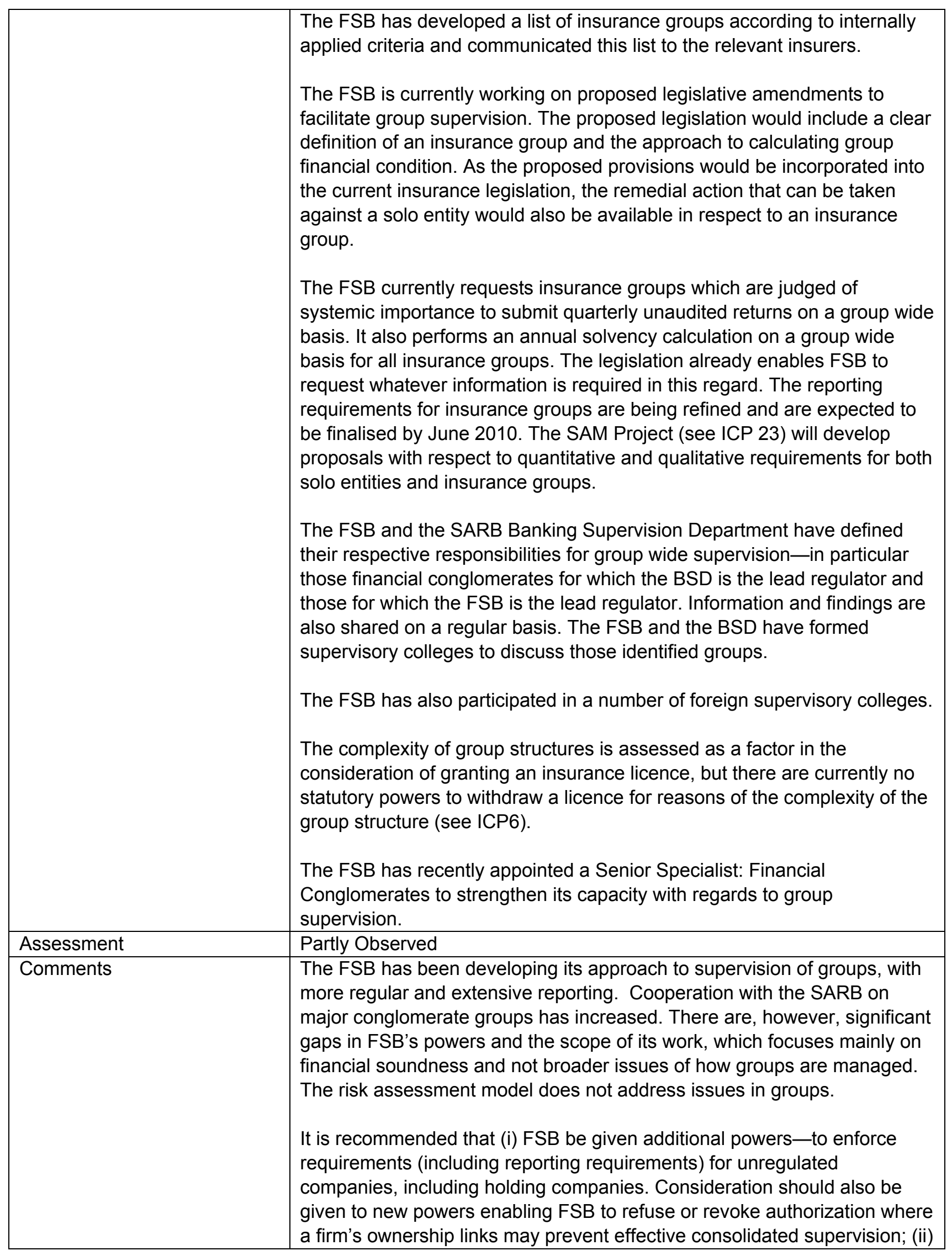




\begin{tabular}{|c|c|c|}
\hline & & $\begin{array}{l}\text { to all groups and should ensure that companies undertaking investment } \\
\text { business, as well as insurance companies, are included in the scope of } \\
\text { consolidated supervision; and (iii) the FSB could also further develop its } \\
\text { approach to lead regulation of conglomerates in cooperation with the } \\
\text { SARB: this could focus on developing a more formal risk assessment and } \\
\text { supervisory program for the whole group (banking and insurance); on } \\
\text { developing a relationship with group senior management covering all } \\
\text { regulatory issues in the group; and on measures to ensure that risk } \\
\text { concentrations across conglomerates are identified and addressed. }\end{array}$ \\
\hline \multicolumn{3}{|l|}{ Prudential Re } \\
\hline Principle 18. & \multicolumn{2}{|c|}{$\begin{array}{l}\text { Risk assessment and management } \\
\text { The supervisory authority requires insurers to recognize the range of risks that they } \\
\text { face and to assess and manage them effectively. }\end{array}$} \\
\hline Description & \multicolumn{2}{|c|}{$\begin{array}{l}\text { There are no requirements or guidelines on risk management for insurance companies. } \\
\text { Insurers are required to report on their risk management practices as part of the } \\
\text { comprehensive annual statutory return submitted by all insurers - this includes } \\
\text { questions on risk management such as whether the insurer has a risk management } \\
\text { function and what are the company's major five risk areas (e.g., statement G9, Risk } \\
\text { Report Issued by Management, annual return for long-term insurers). } \\
\text { Under the risk-based supervisory model for insurers, supervisors are required to assess } \\
\text { the effectiveness of risk management as a mitigant for inherent risks. Areas of potential } \\
\text { weakness are then followed up in onsite work and if confirmed, are reflected in reports } \\
\text { to management and in required action. } \\
\text { The insurance sector in South Africa has not experienced risk management failures in } \\
\text { the financial crisis of the scale or nature of banks and some insurers in a number of } \\
\text { other countries. In general, insurers appeared to have responded swiftly to the } \\
\text { emerging pressures on market and credit risk management. } \\
\text { However, some weaknesses have been made evident by the crisis, including } \\
\text { vulnerability to high rates of lapse and surrenders and more generally to the challenges } \\
\text { posed by product distribution models (for both long-term and short-term business) in } \\
\text { South Africa. Although risk measurement is relatively advanced, stimulated in part by } \\
\text { the early adoption of IFRS, tools such as economic capital models are still developing. }\end{array}$} \\
\hline Assessn & \multirow{2}{*}{\multicolumn{2}{|c|}{$\begin{array}{l}\text { Largely Observed. } \\
\text { As in the area of internal controls, the FSB relies on reporting by insurers and its offsite } \\
\text { and onsite supervisory processes (recently enhanced by the risk-based supervision } \\
\text { model) to detect and deal with risk assessment and risk management weaknesses. } \\
\text { Such issues are also discussed with auditors. The FSB is therefore fully aware of the } \\
\text { importance of effective risk management and the need to ensure that it is adequate - } \\
\text { and that, under the risk-based approach, supervisors can rely on company risk } \\
\text { managers to help ensure overall compliance. This is also evidenced by the inclusion of } \\
\text { requirements in this area in the scope of the SAM project. } \\
\text { It is recommended, however, that the FSB commits to providing more feedback and } \\
\text { guidance to companies on its observations and experience of good and bad risks } \\
\text { management practices. This will both help supervisors to become comfortable with }\end{array}$}} \\
\hline Com & & \\
\hline
\end{tabular}




\begin{tabular}{|c|c|}
\hline & $\begin{array}{l}\text { relying on internal risk management and make companies clear on what are the FSB } \\
\text { expectations in this area. }\end{array}$ \\
\hline Principle 19. & $\begin{array}{l}\text { Insurance activity } \\
\text { Since insurance is a risk taking activity, the supervisory authority requires insurers to } \\
\text { evaluate and manage the risks that they underwrite, in particular through reinsurance, } \\
\text { and to have the tools to establish an adequate level of premiums. }\end{array}$ \\
\hline Description & $\begin{array}{l}\text { There are no specific requirements in relation to underwriting and pricing policies or } \\
\text { their approval by boards of directors. The FSB's approach to insurance risk relies on: } \\
\text { - } \\
\text { holding management responsible for the adequacy of reserving and financial } \\
\text { - } \\
\text { the duties and obligations placed on the statutory actuary, in both long-term } \\
\text { and, since 2008, short-term insurance companies (appointments being subject } \\
\text { to certain requirements and approval of the FSB); the statutory actuary must } \\
\text { certify the soundness of the insurer's insurance activities; } \\
\text { - information reported by insurers on their insurance activities and reinsurance } \\
\text { arrangements as part of the returns; and } \\
\text { - } \\
\text { Dupervision processes focused on careful examination, with Actuarial } \\
\text { Department input, of the annual and quarterly returns, followed up by } \\
\text { communications with the company; and onsite work to assess company } \\
\text { processes in practice. } \\
\text { As the FSB takes a risk-based approach, for many insurers, its supervision of insurance } \\
\text { risk is relatively high level. Where they are comfortable with relying on management and } \\
\text { the statutory actuary (and to some extent also the external auditor), they may look only } \\
\text { at the overall position - reserves adequacy and whether the company is meeting the } \\
\text { Capital Adequacy Requirement. In other cases, more detailed work will be done in } \\
\text { response to concerns or where, for example, a company is moving into new areas of } \\
\text { business. Only in high risk cases, does the FSB review the methodology used and the } \\
\text { reasonability of assumptions in depth. } \\
\text { In respect to reinsurance arrangements, detail on companies' arrangements are } \\
\text { collected via the annual return-data on reinsurance premiums paid, reinsurance } \\
\text { recoveries, extent of catastrophe cover etc (for long-term insurers, statements C9 and } \\
\text { G12). The G12 statement also includes extensive statements on overall reinsurance } \\
\text { strategy and the use of 'financial relief arrangements" (such as finite reinsurance). } \\
\text { These statements have to be signed by the actuary and auditor and, for the G12 } \\
\text { statement, the chairman and a director. However, individual reinsurance arrangements } \\
\text { requirement for high quality collateral. } \\
\text { are checked, unless there is a particular concern. } \\
\text { - }\end{array}$ \\
\hline Assessment & Observed. \\
\hline Comments & $\begin{array}{l}\text { The FSB takes an appropriate risk-based approach to the supervision of insurance risk, } \\
\text { relying on the statutory actuary and targeted consideration of issues in individual } \\
\text { companies. Reinsurance activities are monitored through detailed reports and }\end{array}$ \\
\hline
\end{tabular}




\begin{tabular}{|c|c|}
\hline & $\begin{array}{l}\text { discussions on firms' overall approach. Because retention rates are relatively high and } \\
\text { most reinsurance is with foreign offices of major reinsurers and has to be backed by } \\
\text { collateral, insurers' credit exposures in this area are more limited than in many other } \\
\text { countries. } \\
\text { The use of alternative risk transfer such as finite reinsurance has apparently not been } \\
\text { extensive in South Africa. The FSB has tools to identify and respond to issues but } \\
\text { needs to remain alert, with adequate monitoring resources, to market innovations, } \\
\text { including potential credit risk transfer from the banking system in response to any } \\
\text { regulatory arbitrage opportunities. }\end{array}$ \\
\hline Principle 20. & $\begin{array}{l}\text { Liabilities } \\
\text { The supervisory authority requires insurers to comply with standards for establishing } \\
\text { adequate technical provisions and other liabilities, and making allowance for } \\
\text { reinsurance recoverables. The supervisory authority has both the authority and the } \\
\text { ability to assess the adequacy of the technical provisions and to require that these } \\
\text { provisions be increased, if necessary. }\end{array}$ \\
\hline Description & 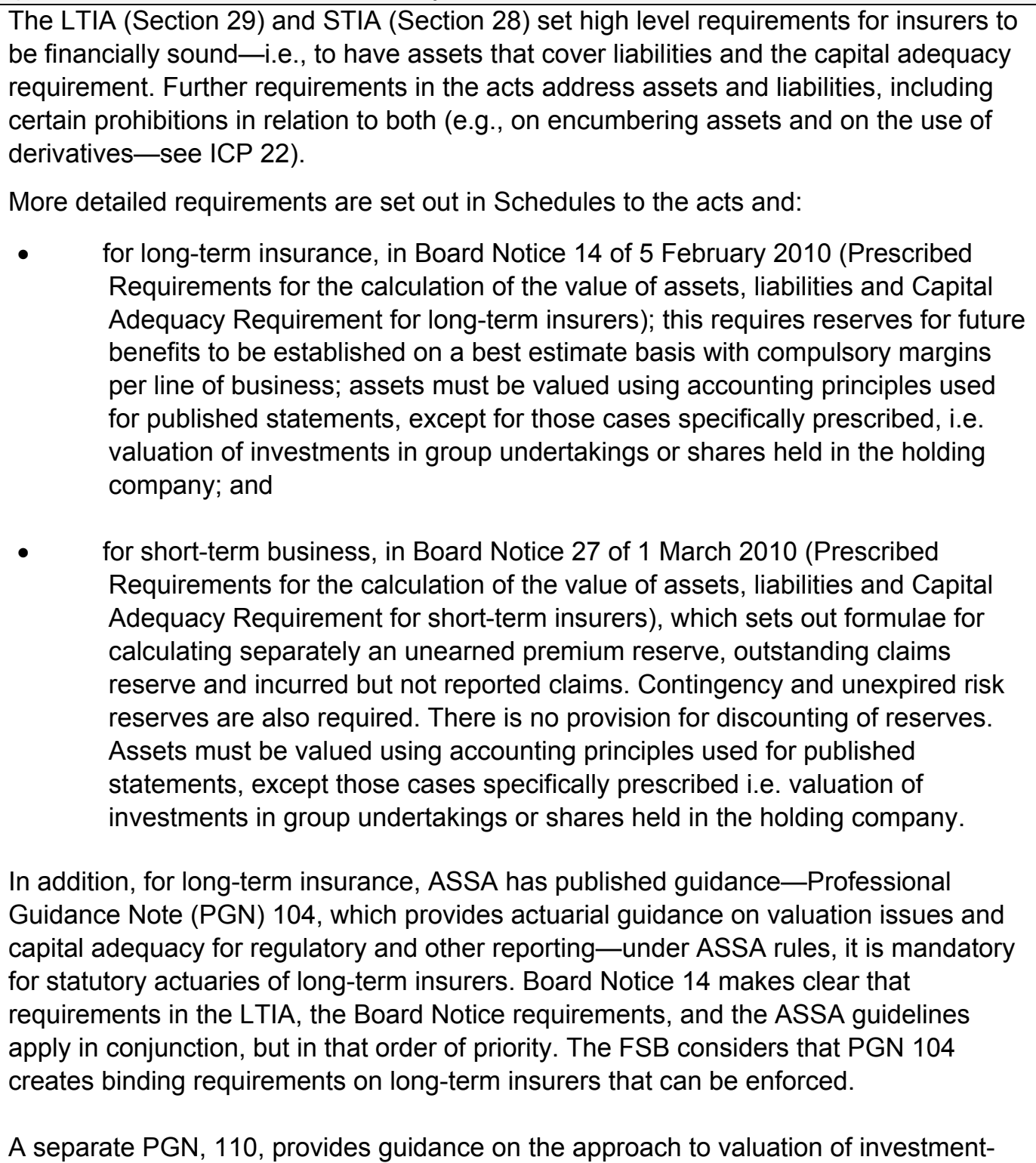 \\
\hline
\end{tabular}




\begin{tabular}{|c|c|}
\hline & 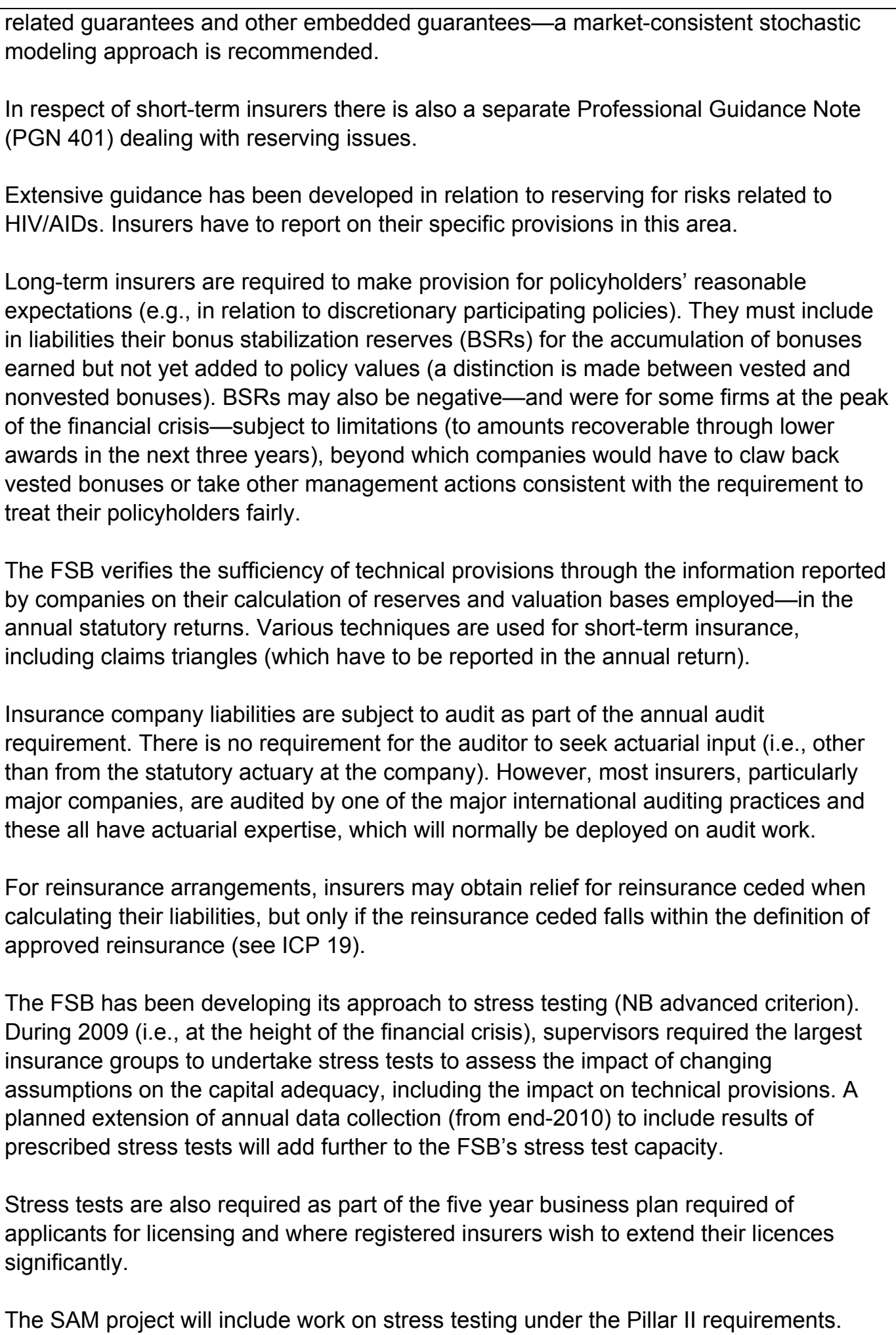 \\
\hline Assessment & Observed. \\
\hline Comments & $\begin{array}{l}\text { Requirements on the establishment of technical provisions are clearly set out and } \\
\text { require insurers to value liabilities appropriately and in some aspects (no provision for } \\
\text { discounting) conservatively. There are clear provisions for the treatment of reinsurance. } \\
\text { The FSB has the authority and expertise, including in its Actuarial Department, and }\end{array}$ \\
\hline
\end{tabular}




\begin{tabular}{|c|c|}
\hline & $\begin{array}{l}\text { extensive information reported by companies, to assess the adequacy of technical } \\
\text { provisions. } \\
\text { The current approach to technical provisions is helpfully being supplemented by } \\
\text { standard and ad hoc stress tests. } \\
\text { For long-term insurers, ASSA guidance is also an important input into reserving } \\
\text { decisions. While the relevant guidance notes are issued by ASSA as a professional } \\
\text { body and apply to statutory actuaries rather than to companies directly, there appears } \\
\text { to be sufficient material in the FSB's own Board Notice to enable enforcement of } \\
\text { appropriate reserving standards on companies. }\end{array}$ \\
\hline Principle 21. & $\begin{array}{l}\text { Investments } \\
\text { The supervisory authority requires insurers to comply with standards on investment } \\
\text { activities. These standards include requirements on investment policy, asset mix, } \\
\text { valuation, diversification, asset-liability matching, and risk management. }\end{array}$ \\
\hline Description & $\begin{array}{l}\text { While the FSB holds the boards and management responsible for the soundness of } \\
\text { investment activities, investment regulations for insurers are detailed and prescriptive. } \\
\text { The LTIA and STIA prescribe the assets that qualify for solvency purposes and prohibit } \\
\text { certain types of asset from being treated as approved. The FSB Board Notices of } 2010 \\
\text { (see ICP 20) set out requirements in more detail. In some cases, the FSB's written } \\
\text { approval must be obtained before certain assets may be used to cover insurance } \\
\text { liabilities, for example encumbered assets. } \\
\text { The FSB may also issue directives to insurers regarding the treatment of specific } \\
\text { assets. For example, a } 2004 \text { Directive (143.A.i) covers investment by long-term insurers } \\
\text { in hedge funds and alternative investment vehicles. } \\
\text { The acts and board notices set out the basis for valuation of assets - and these are } \\
\text { supplemented by ASSA practice notes and also by accounting standards in so far as } \\
\text { the normal approach to asset valuation, for all insurers, is the same for statutory as for } \\
\text { accounting purposes. } \\
\text { The FSB has issued no formal guidance and there are no requirements in the insurance } \\
\text { acts or regulations on insurers' overall strategic investment policy, risk management } \\
\text { systems or internal controls specifically in relation to investments. Insurers are asked to } \\
\text { report information about their approach and certify its adequacy in the annual return. } \\
\text { This includes questions relating to asset and liability matching. Insurers' answers are } \\
\text { then subject to follow-up work by supervisors both offsite and in onsite visit work, taking } \\
\text { a risk-based approach. Guidance in these areas will be developed as part of the SAM } \\
\text { project. } \\
\text { There are no explicit provisions for staff involved with investment activities to have } \\
\text { appropriate levels of skills and integrity; or for insurers to have contingency plans to } \\
\text { mitigate the effect of deteriorating investment conditions. These issues may be } \\
\text { addressed in supervision, depending on the assessment of risk at each firm. } \\
\text { Requirements on safekeeping of assets are covered in the Financial Institutions } \\
\text { (Protection of Funds) Act. }\end{array}$ \\
\hline & Largely Observed. \\
\hline Com & nents in relation to assets available to meet solvency \\
\hline
\end{tabular}




\begin{tabular}{|c|c|}
\hline & $\begin{array}{l}\text { requirements -it has adopted a prescriptive approach (with, as in other areas, } \\
\text { extensive reporting) rather than a principles-based approach. Remaining South African } \\
\text { exchange controls (the } 20 \text { percent of total assets limit on foreign investments) also } \\
\text { serve to constrain insurers' investment freedom, although the impact on risk is less } \\
\text { clear given the predominance of Rand liabilities (although insurers may prefer to invest } \\
\text { shareholders' funds abroad). } \\
\text { Given the prescriptive approach, the need for extensive requirements in relation to risk } \\
\text { management and controls in relation specifically to investment assets is more limited } \\
\text { than it would be otherwise. The supervisors address many of the issues, including } \\
\text { through onsite supervision. However it is recommended that the FSB develop } \\
\text { requirements in relation to risk management and controls over investments, drawing on } \\
\text { their experience from supervision of good and bad practice-this is already planned for } \\
\text { the SAM project. }\end{array}$ \\
\hline $\mathrm{Pr}$ & $\begin{array}{l}\text { Derivatives and similar commitments } \\
\text { The supervisory authority requires insurers to comply with standards on the use of } \\
\text { derivatives and similar commitments. These standards address restrictions in their } \\
\text { use and disclosure requirements, as well as internal controls and monitoring of the } \\
\text { related positions. }\end{array}$ \\
\hline Des & $\begin{array}{l}\text { The LTIA (Section 34(2)) and STIA (Section 33(2)) allow insurers to invest in derivatives } \\
\text { but only for specific purposes: as an asset in relation to linked policies, as assets in } \\
\text { excess of those needed to back liabilities and for hedging and efficient portfolio } \\
\text { management. The effect of these requirements is to prevent insurers from trading in } \\
\text { derivatives or using them to create risks to the insurer itself other than counterparty } \\
\text { risks. } \\
\text { Detailed information has to be reported by the insurer on these derivative instruments in } \\
\text { the statutory returns. The auditors and statutory actuary (in the case of a long-term } \\
\text { insurer) must report annually on derivative instruments. } \\
\text { The FSB does not have specific disclosure requirements in relation to derivatives (see } \\
\text { ICP } 26 \text { ). } \\
\text { The FSB has issued no formal guidance and there are no requirements in the insurance } \\
\text { acts or regulations on insurers' use of derivatives policies, risk management systems or } \\
\text { internal controls specifically in relation to derivatives. There are no explicit requirements } \\
\text { for staff with appropriate levels of skills or for the board of directors to ensure there is } \\
\text { capability to verify pricing independently in respect to OTC derivatives. There are no } \\
\text { requirements in relation to internal audit and derivatives. } \\
\text { All these issues are addressed to an extent in supervision, depending on the } \\
\text { assessment of risk at each firm. Questions in relation to some of these issues are also } \\
\text { covered in the annual statutory return. In particular, statement G8 (Risk Report issued } \\
\text { by management) has extensive questions on the role of the board in relation to } \\
\text { derivatives, system and control and particular issues with OTC derivatives. Insurers are } \\
\text { asked particular questions on credit derivatives, including limits and valuation issues. } \\
\text { Guidance in these areas will be developed as part of the SAM project. } \\
\text { a }\end{array}$ \\
\hline & Largely Observed. \\
\hline Comn & lies on $g$ \\
\hline
\end{tabular}




\begin{tabular}{|c|c|}
\hline & $\begin{array}{l}\text { in relation to financial soundness, extensive reporting and their supervision work to } \\
\text { identify and address issues with use of derivatives by insurers. The approach is } \\
\text { underpinned by requirements in the legislation that have the effect of limiting the } \\
\text { derivatives activities of insurers. In practice, there have not been significant concerns } \\
\text { with insurers' use of derivatives in South Africa, in the financial crisis or before; and in } \\
\text { particular insurers have not been engaged in credit derivatives or credit protection } \\
\text { business generally of the sort that has created stress for insurance companies in other } \\
\text { markets. } \\
\text { Nonetheless, it is recommended that the FSB develop fuller requirements on the use of } \\
\text { derivatives, drawing on their experience from supervision of good and bad practice. } \\
\text { This is already planned for the SAM project. The FSB should consider whether there } \\
\text { are any particular areas where the introduction of requirements ahead of the SAM } \\
\text { project timetable may be necessary. Alternatively, the FSB could consider including } \\
\text { derivatives management issues in its thematic supervisory work program. }\end{array}$ \\
\hline Principle 23. & $\begin{array}{l}\text { Capital adequacy and solvency } \\
\text { The supervisory authority requires insurers to comply with the prescribed solvency } \\
\text { regime. This regime includes capital adequacy requirements and requires suitable } \\
\text { forms of capital that enable the insurer to absorb significant unforeseen losses. }\end{array}$ \\
\hline Description & $\begin{array}{l}\text { There are detailed provisions in the LTIA and STIA and FSB board notices covering } \\
\text { valuation of assets and liabilities and overall capital adequacy. } \\
\text { Long-term insurers must have assets that exceed liabilities and capital adequacy } \\
\text { requirements (CAR) determined by its statutory actuary as the highest of: } \\
\text { - } \quad \text { an amount that will ensure that the liability of the insurer under each policy is } \\
\text { not less than the amount that will become available to the policyholder on the } \\
\text { surrender or lapse of that policy, making due allowance for the reasonable } \\
\text { expectations of the policyholder; } \\
\text { - } \\
\text { the amount determined in accordance with Actuarial Society (ASSA) guidelines } \\
\text { (PGN 104) for calculating the capital adequacy requirement (see below); and } \\
\text { the minimum capital adequacy requirement, which is to be the higher of: (i) R10 } \\
\text { million; (ii) an amount representing operating expenses, multiplied by } 13 \text { and } \\
\text { divided by } 52 \text { or, if different, the number of weeks included in the reporting } \\
\text { period; and (iii) an amount equal to } 0.3 \text { percent of its gross contingent liabilities } \\
\text { under unmatured policies. } \\
\text { The ASSA guideline PGN } 104 \text { calls for the CAR to be large enough to provide a } \\
\text { significant cushion against adverse experience, but not so large as to endanger the } \\
\text { viability of the long-term insurance industry. A number of capital cushions are required } \\
\text { to cover specific events- where practical, the target confidence interval for the size of } \\
\text { the cushion is } 95 \text { percent. The overall cushion is then calculated as less than the sum of } \\
\text { the individual cushions, to allow for diversification amongst risks. Correlation } \\
\text { assumptions are specified in PGN } 104 \text {. } \\
\text { The overall framework in PGN } 104 \text { now provides for long-term insurers to meet the } \\
\text { higher of: }\end{array}$ \\
\hline
\end{tabular}




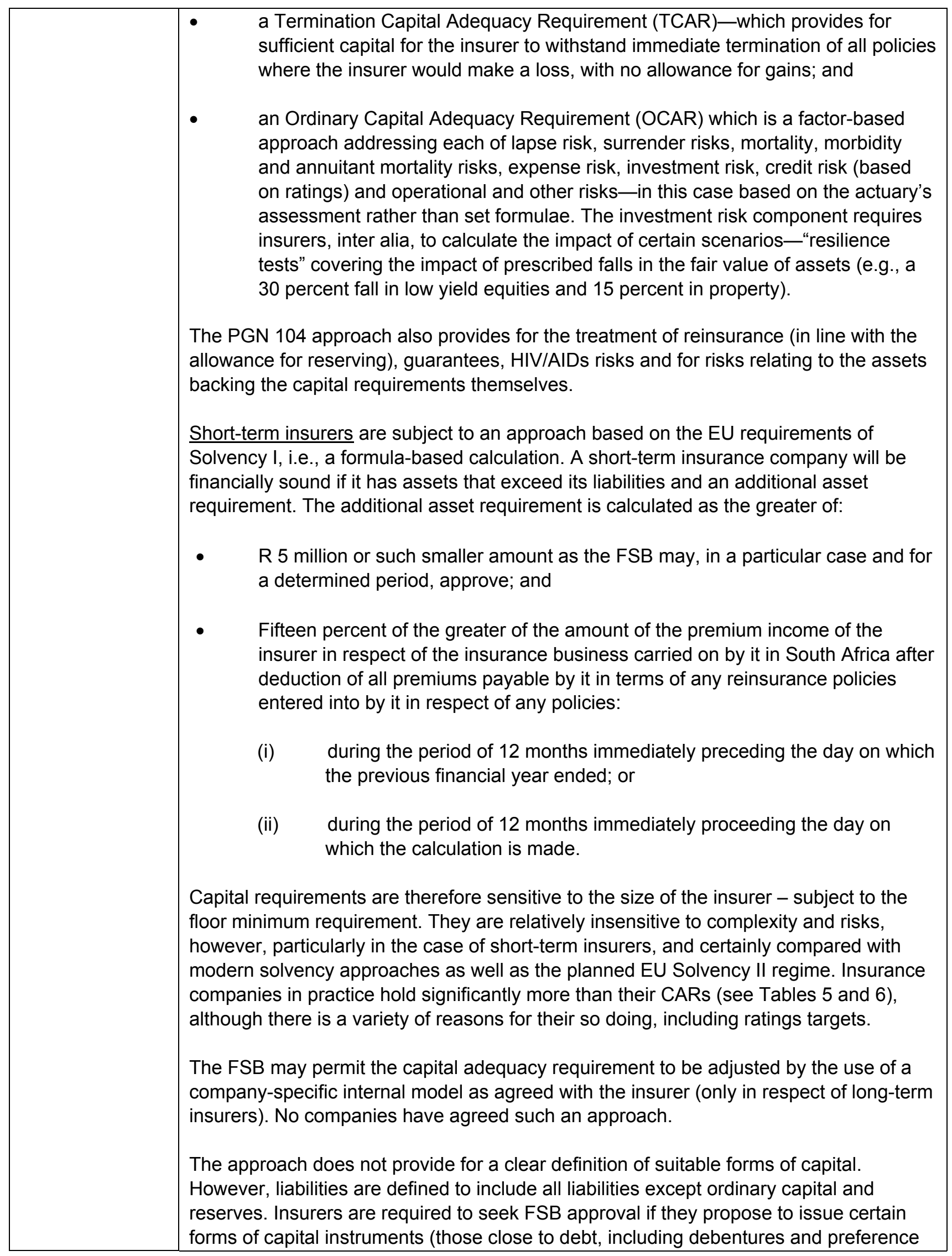




\begin{tabular}{|c|c|}
\hline & $\begin{array}{l}\text { shares unless compulsorily convertible into ordinary shares). (LTIA Section 24, STIA, } \\
\text { Section 23). } \\
\text { There are no established solvency control levels triggering intervention by the FSB (see } \\
\text { also ICP 14)-although the FSB does have internal guidance on appropriate responses } \\
\text { by supervisors. Intervention using regulatory powers can take place only when the } \\
\text { company is no longer financially sound-which means in breach of its CAR. } \\
\text { The auditor and also the statutory actuary in the case of a long-term insurer must certify } \\
\text { that the requirements regarding a minimum capital adequacy and solvency margin have } \\
\text { been met. Supervision focuses on the statutory returns and not on the published } \\
\text { financial statements. } \\
\text { There are no explicit provisions on the calculation of insurance group capital that would } \\
\text { address risks of multiple gearing and intra-group transactions (see ICP 17). } \\
\text { The capital requirements cover domestic and foreign branches of South African } \\
\text { companies. Branches of foreign companies may not be licensed in South Africa (see } \\
\text { ICP } 6 \text { ). } \\
\text { All long-term insurers are in addition subject to a minimum capital of } 0.3 \text { percent of total } \\
\text { liabilities. This particularly affects companies who only undertake linked insurance } \\
\text { business (investment business with an insurance wrapper but no guarantee or life } \\
\text { cover) because of the limited extent of their risks. } \\
\text { The FSB has been developing its approach to stress testing (NB advanced criterion). } \\
\text { During } 2009 \text { (i.e., at the height of the financial crisis), supervisors required the largest } \\
\text { insurance groups to undertake stress tests to assess the impact of changing } \\
\text { assumptions on the capital adequacy, including the impact on technical provisions. A } \\
\text { planned extension of annual data collection (from end-2010) to include results of } \\
\text { prescribed stress tests will add further to the FSB's stress test capacity. } \\
\text { (referred to as the Solvency Assessment and Management Project or SAM). SAM will } \\
\text { be based on Solvency II but will also consider solvency structures of other jurisdictions } \\
\text { such as Australia, Canada and Switzerland. (NB advanced criterion). }\end{array}$ \\
\hline Assessment & Observed. \\
\hline Comments & $\begin{array}{l}\text { The FSB has generally well-developed standards on solvency and capital adequacy. } \\
\text { The approach is more risk-based for long-term than short-term insurance. The recent } \\
\text { extension of the long-term requirements to incorporate credit and operational risks has } \\
\text { strengthened the approach significantly. The resilience tests represent a dynamic, } \\
\text { forward-looking component. Insurance risks, including annuitant longevity risk, are well- } \\
\text { covered. } \\
\text { The FSB had been working on a major overhaul of the short-term insurance } \\
\text { requirements-a project to introduce Financial Condition Reporting (FCR) based } \\
\text { around a requirement to meet an overall } 99.5 \text { percent solvency standard. This work has } \\
\text { been incorporated into a much larger project, SAM, following a recent decision that the } \\
\text { FSB's regime will be subject to comprehensive modernization and development, both }\end{array}$ \\
\hline
\end{tabular}




\begin{tabular}{|c|c|}
\hline & $\begin{array}{l}\text { for its own sake and to ensure that it can be viewed as equivalent to the EU Solvency II } \\
\text { regime (the framework directive for which was adopted in April } 2009 \text { and which takes } \\
\text { effect in late 2012). } \\
\text { While the SAM project will not deliver final revised CAR and other requirements until } \\
\text { (i.e., taking effect in) 2014, there are plans to introduce interim reform measures in } 2012 \\
\text { and priority should be accorded to the short-term insurance regime given that it is the } \\
\text { less risk-based. } \\
\text { FSB could also consider reforms at that time to its approach to solvency control levels- } \\
\text { i.e., articulating a policy for the use of its powers to intervene formally (or informally) } \\
\text { before the point at which an insurance company is in breach of its CAR, as it may under } \\
\text { the LTIA and STIA. While individual insurance companies can be expected to decide } \\
\text { themselves the appropriate level of capital to hold above the CAR, there is scope for } \\
\text { some uncertainty, in the absence of control levels or a Pillar II process generally, about } \\
\text { what the FSB considers appropriate capital adequacy cover above CAR for an } \\
\text { individual company given its risk profile. } \\
\text { In the interim, FSB supervisors need to be vigilant as to insurance companies reducing } \\
\text { CAR coverage levels by taking on extra risks that may not be adequately covered, for } \\
\text { any individual insurance company, by the minimum CAR. The risk-based supervisory } \\
\text { model that the FSB is now implementing should equip it to do so. } \\
\text { In the longer run, the SAM project promises a comprehensive overhaul of the solvency } \\
\text { and capital framework, including the introduction of formal Pillar II and III requirements } \\
\text { and qualitative standards on risk management and other matters closely related to } \\
\text { solvency issues. This project appears to be especially well organized and resourced, } \\
\text { with appropriate industry participation. }\end{array}$ \\
\hline \multicolumn{2}{|c|}{ Markets and consumers } \\
\hline Principle 24. & $\begin{array}{l}\text { Intermediaries } \\
\text { The supervisory authority sets requirements, directly or through the supervision of } \\
\text { insurers, for the conduct of intermediaries. }\end{array}$ \\
\hline Description & $\begin{array}{l}\text { The FAIS Act, Section 7, requires insurance advisors and intermediaries to be licensed } \\
\text { along with other financial services providers (FSPs). Companies licensed as insurers } \\
\text { under the LTIA or STIA are exempted from the need for licensing under FAIS, provided } \\
\text { they plan only to provide intermediary services. If they want to offer advice, they need } \\
\text { an FAIS license. } \\
\text { There are various licensing requirements (FAIS Act, Section } 8 \text { ), including integrity and } \\
\text { honesty, professional competence and financial soundness. } \\
\text { Some } 13,800 \text { FAIS licenses have been granted in total (the FAIS Act took effect in } \\
2004) \text {, of which some } 80 \text { percent cover insurance advisory or intermediary business. } \\
\text { Intermediaries may act as independent or tied agents on behalf of insurance and other } \\
\text { product providers or they may act as brokers to the client. There is no distinction in law. } \\
\text { (A longer term project on the intermediary market that may address this distinction is } \\
\text { planned under the NT's program for contractual savings-see NT Discussion Paper, } \\
\text { "Contractual Savings in the Life Industry," March 2006.) Commercial lines brokers are } \\
\text { required to be licensed as well as retail intermediaries. }\end{array}$ \\
\hline
\end{tabular}


Under the Policyholder Protection Rules for insurers (see ICP 25), insurers may deal only with intermediaries licensed under the FAIS Act.

Once licensed, intermediaries are subject to a General Code of Conduct issued under the FAIS Act that applies to all FSPs. This covers a wide range of requirements relating to disclosures to clients, the basis for giving advice, clients' assets and money, and handling of complaints. It requires intermediaries to at all times render financial services honestly, fairly, with due skill, care and diligence, and in the interests of clients and the integrity of the financial services industry.

The Code sets out rules covering representations made to a client by a FSP; mandates the provision of clear information to clients concerning product suppliers and any interest of the FSP in the suppliers; requires the provider to supply the client with detailed, specified information concerning the contracts entered into with product suppliers; and requires the provider to conduct a thorough needs analysis and ensure that any advice provided is appropriate to the needs and risk profile of the client.

Similar provisions apply to insurance companies offering advice under the Policyholder Protection Rules (see ICP 25).

Commission paid by insurance companies to intermediaries is subject to caps, for both long-term and short-term insurance products. On investment products provided by longterm insurers, only 50 percent of the total commission may be paid upfront-a recent provision aimed at reducing the incentives on intermediaries to switch clients from one product to another that had previously been a feature of the market.

The General Code of Conduct contains provisions on handling of clients' assets (Section VII, Custody of Financial Products and Funds). This requires, inter alia, that intermediaries open and maintain a separate account for client funds, at a bank, pay in funds promptly (within one day); ensure that such accounts only contains funds of clients and not those of the provider; and ensure that any interest accruing to the funds in the separate account is payable to the client or the owner of the funds.

Intermediaries who handle client assets are subject to different financial resources requirements from those which do not do so - but at present the requirement is only that assets exceed liabilities (there are no requirements where no client assets are held). There are plans to introduce an expenditure-based requirement for client money holders later this year. Intermediaries acting for short-term insurers are, in addition, required under the STIA (and regulations made under it) to hold an insurance policy or bank guarantee in respect of premiums collected on behalf of an insurer.

Market conduct on-site inspections are carried out by the FSB, FAIS Division. The division has its own model of risk-based assessment and supervision. A project is underway to integrate this with the Insurance Division's model by mid-2010. All intermediaries can expect an onsite visit under the FAIS approach every seven to ten years.

A statutory ombudsman scheme handles complaints against intermediaries and insurers with FAIS licenses in relation to activities covered by the FAIS Act. 


\begin{tabular}{|c|c|}
\hline & $\begin{array}{l}\text { The FSB has extensive powers under the FAIS act to take action against intermediaries } \\
\text { in case of breaches of its requirements. }\end{array}$ \\
\hline Assessment & Observed. \\
\hline Comments & $\begin{array}{l}\text { The FSB's approach to intermediary regulation is relatively complex, with different, if } \\
\text { similar, legislation and rules applying to insurance companies acting as distributors of } \\
\text { their own products compared with independent intermediaries; and different approaches } \\
\text { to supervision. The approach is still relatively new and developing. However, it appears } \\
\text { comprehensive and FSB has adequate powers to enforce compliance. } \\
\text { There is a particular need to deal with the extension of the work of some intermediaries } \\
\text { into a quasi-underwriting role through binder agreements - the FSB and NT are } \\
\text { addressing the need for regulations to add to provisions added recently to the STIA and } \\
\text { the LTIA. } \\
\text { Longer term, there remains a broader market structure challenge, as outlined in } 2006 \\
\text { NT work, to move to a basis of remuneration of intermediaries that is more aligned with } \\
\text { the capacity in which they operate, whether as agents of insurers or independent } \\
\text { brokers acting on behalf of clients. }\end{array}$ \\
\hline Principle 25. & $\begin{array}{l}\text { Consumer protection } \\
\text { The supervisory authority sets minimum requirements for insurers and intermediaries } \\
\text { in dealing with consumers in its jurisdiction, including foreign insurers selling products } \\
\text { on a cross-border basis. The requirements include provision of timely, complete and } \\
\text { relevant information to consumers both before a contract is entered into through to the } \\
\text { point at which all obligations under a contract have been satisfied. }\end{array}$ \\
\hline Description & $\begin{array}{l}\text { The Insurance and FAIS Act legislation and the requirements made under them set } \\
\text { minimum standards for insurers and intermediaries in dealing with clients. The core sets } \\
\text { of requirements are the General Code of Conduct for financial services providers (FAIS } \\
\text { licensees—see ICP24) and the Policyholder Protection Rules (PPRs) for insurers. } \\
\text { For insurers, the high level requirements are set out in Part VII of both LTIA and STIA. } \\
\text { These address: } \\
\text { - } \\
\text { Business practices-including provisions requiring potential buyers of credit } \\
\text { insurance to be given a choice on whether to take it, a prohibition on } \\
\text { inducements, provisions on collection of premiums by intermediaries, copy of } \\
\text { policy and inspection of policy records and certain undesirable business } \\
\text { practices. } \\
\text { Policies: The Acts prescribe matters relating to limitations on policy benefits, the } \\
\text { validity of contracts, misrepresentation and failure to disclose material } \\
\text { information. LTIA Section } 49 \text { sets out provisions on the limitation of } \\
\text { remuneration to intermediaries, the basis for maximum commission } \\
\text { requirements set out in separate regulations. } \\
\text { Policyholder protection: the Acts provides for the Minister of Finance to make } \\
\text { rules (there are proposals to give this power to the FSB in future). } \\
\text { Both the General Code of Conduct and PPRs set out requirements on fair treatment of } \\
\text { policyholders at point of sale, including disclosure standards and requirements to } \\
\text { assess the suitability of particular financial products for the client's risk profile etc. The }\end{array}$ \\
\hline
\end{tabular}




\begin{tabular}{|c|c|}
\hline & $\begin{array}{l}\text { PPR has requirements applying to business marketed directly without the use of } \\
\text { intermediaries-particularly important for short-term business. } \\
\text { There are requirements in the General Code and PPRs for insurers and intermediaries } \\
\text { to provide training to employees advising and intermediating with clients. } \\
\text { Market conduct onsite visits focus on complaints handling procedures, risk of incorrect } \\
\text { benefit payments, disclosures to prospective policyholders, undesirable selling practices } \\
\text { by intermediaries and complaints received from the public not dealt with through the } \\
\text { ombudsman schemes. } \\
\text { The respective South African insurance industry associations have established } \\
\text { ombudsman schemes (known as ombuds in South Africa), to deal with complaints that } \\
\text { are contractual in nature and relate to members. The Financial Services Ombud } \\
\text { Schemes Act No. } 37 \text { of } 2004 \text {, regulates voluntary ombud schemes and establishes a } \\
\text { statutory ombud to address complaints in respect of which a voluntary ombud or the } \\
\text { FAIS Ombud does not have jurisdiction. } \\
\text { The FSB issues media releases to warn the public against unregistered financial } \\
\text { services providers. The FSB has established a dedicated Consumer Education } \\
\text { Department that has various initiatives in place to educate consumers, including on } \\
\text { insurance related matters. (NB advanced criteria). }\end{array}$ \\
\hline Assessment & Observed \\
\hline Comments & $\begin{array}{l}\text { The FSB has a range of rules and requirements addressing key areas of consumer } \\
\text { protection for policyholders at the point of sale and after sales. A range of ombudsman } \\
\text { services provide additional protection in the case of complaints handling. The FSB is } \\
\text { focusing on consumer protection in its supervisory work, both offsite work and in onsite } \\
\text { work, including through increased thematic programs. Cooperation within the FSB on } \\
\text { market conduct issues, and with other regulators such as the NCR, has been improved. } \\
\text { Despite these efforts, the FSB observes significant issues in relation to the fair } \\
\text { treatment of customers, in both the long-term insurance sector (those highlighted in the } \\
\text { NT work on contractual savings in } 2006 \text { but more recently in the risk and protection } \\
\text { business also); and in short-term insurance business, including issues in FSB's current } \\
\text { work on binder agreements. } \\
\text { The new powers for FSB to levy fines and force compensation via its Enforcement } \\
\text { Committee should add significantly to the effectiveness of FSB's overall approach, } \\
\text { underlining that sanctions can and will be sought for market conduct failures. FSB is } \\
\text { also starting a major initiative to improve standards of customer treatment (its Treating } \\
\text { Customers Fairly program - TCF) in all aspects of the business. Longer run, this will } \\
\text { need to focus on market structure issues, to address the conflicts of interest that appear } \\
\text { to underlie many of the problems it has encountered. }\end{array}$ \\
\hline Principle 26. & $\begin{array}{l}\text { Information, disclosure } \& \text { transparency toward the market } \\
\text { The supervisory authority requires insurers to disclose relevant information on a timely } \\
\text { basis in order to give stakeholders a clear view of their business activities and } \\
\text { financial position and to facilitate the understanding of the risks to which they are } \\
\text { exposed. }\end{array}$ \\
\hline Descri & ompanies under the Companies Act, 197 \\
\hline
\end{tabular}




\begin{tabular}{|c|c|}
\hline & $\begin{array}{l}\text { which requires them to publish financial statements covering a wide range of } \\
\text { information - particularly since the introduction of IFRS in } 2005 \text { (IFRS } 4 \text { prescribes a } \\
\text { number of disclosures on risk sensitivities etc). Mutual insurers are also required to } \\
\text { draw up financial statements in accordance with the requirements in the Companies } \\
\text { Act. } \\
\text { Insurers that are not public companies are also required to appoint auditors and have } \\
\text { their annual financial statements audited. These need to be submitted to the } \\
\text { Companies Registry but they are not required to be disclosed directly to stakeholders } \\
\text { and may not be readily available where, for example, policyholders ask for them. Parts } \\
\text { of the regulatory returns (annual not quarterly) are nonconfidential and may be made } \\
\text { available by companies or the FSB (the FSB charges R } 150 \text { per return). } \\
\text { The FSB has no requirements of its own on disclosure by insurance companies to } \\
\text { stakeholders. Nor does it monitor the disclosures made by insurance companies in } \\
\text { terms of whether they provide information to all stakeholders of all companies (including } \\
\text { insurance intermediaries and advisers) that will enable them to take a clear view of the } \\
\text { insurer's business and financial position. (The JSE monitors disclosures by public } \\
\text { companies). }\end{array}$ \\
\hline Assessment & Largely Observed \\
\hline Comments & $\begin{array}{l}\text { While the FSB has limited disclosure requirements, there is a particularly wide range of } \\
\text { information available on the financial position, management and risks of insurers which } \\
\text { are public companies-almost all. It is nonetheless recommended that the FSB review } \\
\text { the full range of disclosures that would be useful to stakeholders, drawing on IAIS work, } \\
\text { and then consider to what extent these are met by existing requirements on public } \\
\text { companies and where there are gaps in available information. The FSB should consider } \\
\text { whether they can make the nonconfidential parts of returns more readily available for all } \\
\text { companies. }\end{array}$ \\
\hline Princ & $\begin{array}{l}\text { Fraud } \\
\text { The supervisory authority requires that insurers and intermediaries take the necessary } \\
\text { measures to prevent, detect and remedy insurance fraud. }\end{array}$ \\
\hline Descr & $\begin{array}{l}\text { The FSB does not have specific powers in legislation to make and enforce rules in } \\
\text { relation to insurance fraud. Its role in respect to insurance fraud is to use its supervisory } \\
\text { powers to monitor for and report instances of fraud to the criminal authorities and to } \\
\text { cooperate in investigations and prosecutions. It has full powers to exchange information } \\
\text { and cooperate with the police and the FIC. } \\
\text { Insurance fraud is not addressed in legislation but fraud is a common law criminal } \\
\text { offence and prosecutions for insurance fraud are undertaken and convictions obtained. } \\
\text { The FSB requires insurance companies to meet high standards of integrity-in } \\
\text { particular through its requirements for fit and proper managers and other key } \\
\text { functionaries. The general corporate governance regime creates similar expectations on } \\
\text { insurance companies. } \\
\text { Insurance intermediaries licensed by the FSB under the FAIS Act are specifically } \\
\text { required under the Code of Conduct for Authorized Financial Services Providers to have } \\
\text { resources, procedures and systems to eliminate as far as possible the risk of fraud } \\
\text { (causing loss to clients, product suppliers and others). However, there are no such } \\
\text { requirements on insurance companies. }\end{array}$ \\
\hline
\end{tabular}




\begin{tabular}{|c|c|}
\hline & $\begin{array}{l}\text { Insurance companies and intermediaries are required to report suspicious transactions } \\
\text { to the FIC. } \\
\text { Through its supervision work, and taking a risk-based approach, the FSB considers } \\
\text { whether insurance companies are exposed to fraud risks and the adequacy of their } \\
\text { controls. The FSB Inspectorate Department may carry out investigations where there is } \\
\text { evidence of fraud. } \\
\text { FSB supports the sharing by insurance companies of insurance claims fraud data } \\
\text { through the South African Insurance Crime Bureau (SAICB). Participation is not a } \\
\text { requirement. } \\
\text { The FSB cooperates in practice with other authorities and with authorities in other } \\
\text { countries on cases involving potential fraud. }\end{array}$ \\
\hline Assessment & Partly Observed. \\
\hline Comments & $\begin{array}{l}\text { The FSB has a high degree of awareness of fraud issues and addresses insurance } \\
\text { companies' controls against fraud in its supervision work. However, only insurance } \\
\text { intermediaries and not insurance companies are subject to specific requirements on } \\
\text { fraud prevention. } \\
\text { It is recommended that the adequacy of FSB's powers to make and enforce } \\
\text { requirements under the insurance legislation is reviewed and that requirements are } \\
\text { introduced for insurance companies. }\end{array}$ \\
\hline \multicolumn{2}{|c|}{ Anti-money laundering, combating the financing of terrorism } \\
\hline Principle 28. & $\begin{array}{l}\text { Anti-money laundering, combating the financing of terrorism (AML/CFT) } \\
\text { The supervisory authority requires insurers and intermediaries, at a minimum those } \\
\text { insurers and intermediaries offering life insurance products or other investment related } \\
\text { insurance, to take effective measures to deter, detect and report money laundering and } \\
\text { the financing of terrorism consistent with the Recommendations of the Financial Action } \\
\text { Task Force on Money Laundering (FATF). }\end{array}$ \\
\hline Description & $\begin{array}{l}\text { Anti-money laundering legislation in South Africa came into effect in 2003, with } \\
\text { subordinate legislation coming into effect in } 2004 \text {. The Financial Intelligence Centre } \\
\text { ("FIC"), the body responsible for the facilitation of AML/CFT controls under the Financial } \\
\text { Intelligence Centre Act ("FICA") also started operating during } 2004 \text {. } \\
\text { Under recent amendments to FICA, the FSB, as one of the relevant supervisory } \\
\text { institutions, is responsible for ensuring compliance with FICA. In other words, FICA's } \\
\text { powers and responsibilities for AML work on insurers are effectively delegated to FSB. } \\
\text { The FSB sets no requirements generally applicable to insurers in the area of AML/CFT. } \\
\text { In 2008, South Africa was assessed for compliance with the Financial Action Task } \\
\text { Force (FATF) AML/CFT standards by the FATF and the Eastern and Southern Africa } \\
\text { Anti-Money Laundering Group (ESAAMLG). The resulting mutual evaluation report was } \\
\text { published in February 2009-but was based on the FICA before the recent } \\
\text { amendments. The report noted various areas of partial compliance with the FATF } \\
\text { standards in relations to insurance: } \\
\text { absence of specific requirements in relation to Customer Due Diligence (CDD) } \\
\text { in case of a suspicion of money-laundering, identifying and verifying beneficial }\end{array}$ \\
\hline
\end{tabular}




\begin{tabular}{|c|c|}
\hline & $\begin{array}{l}\text { owners, ongoing due diligence, including for higher risk categories of customer } \\
\text { including politically exposed persons (PEPs); } \\
\text { - } \\
\text { much higher than in FATF examples; } \\
\text { - } \quad \text { absence of compliance function at management level or adequately resourced } \\
\text { internal audit requirement to test AML compliance; } \\
\text { - } \quad \text { low level of compliance with AML/CFT requirements (including attention to } \\
\text { sanctions) in insurance sector; } \\
\text { absence of legal requirement for fit and proper test for directors of long-term } \\
\text { insurers (see ICP } 7 \text {, however); } \\
\text { no sanctions applied against insurers despite low level of compliance with } \\
\text { AML/CFT requirements; } \\
\text { no FSB powers to conduct inspections in relation to AML/CFT compliance. } \\
\text { Many of these issues have been dealt with through amendments to FICA. As } \\
\text { mentioned, this has clarified the relationship between the FIC and FSB. The FSB now } \\
\text { uses its powers to impose conditions on licenses to require companies to comply with } \\
\text { FICA. The two authorities are able to cooperate and exchange information freely. While } \\
\text { the FIC conducts onsite work on its own on insurance companies, the FIC and FSB also } \\
\text { conduct joint on-site visits to long-term insurers. For FSB, these onsite visits are } \\
\text { separate from the general onsite work done under the risk-based approach (although } \\
\text { AML/CFT issues are integrated into the risk-based model via assessment of } \\
\text { legal/regulatory risk). } 12 \text { AML/CFT visits were conducted by FSB in the year to March } \\
\text { 2009. } \\
\text { FSB collects information on insurance company compliance with FICA requirements as } \\
\text { part of its annual return. In addition, all long-term insurers are required to report on } \\
\text { FICA compliance when submitting quarterly returns. } \\
\text { } \\
\text { - }\end{array}$ \\
\hline Assessment & Observed. \\
\hline Comments & $\begin{array}{l}\text { Requirements in relation to AML/CFT issues for insurers are set out in the legislation on } \\
\text { the FIC and the role of FSB is to monitor compliance with those requirements, conduct } \\
\text { compliance work onsite, jointly with FIC as appropriate, and to support FIC in raising } \\
\text { standards in the insurance sector generally. There is a high degree of awareness of the } \\
\text { scope for long-term insurance products to be used for money-laundering purposes. } \\
\text { The recent mutual evaluation review highlighted a number of institutional weaknesses in } \\
\text { the South African approach and these are being addressed through legislative change, } \\
\text { although implementation is still proceeding. It remains for FSB to work with FIC to } \\
\text { ensure that overall relatively weak compliance by insurers improves. } \\
\text { It is recommended that FSB consider (i) the recruitment of some specialist expertise in } \\
\text { this area-recognizing that much of the work of raising standards through supervision } \\
\text { should fall to the insurance supervisory agency; and (ii) that AML/CFT issues, } \\
\text { particularly insurance companies' high level approach to and resourcing of compliance, }\end{array}$ \\
\hline
\end{tabular}


be addressed as part of regular onsite work on individual companies as well as through thematic visits. 